Western University

Scholarship@Western

Chemistry Publications

Chemistry Department

Spring 3-1-2019

Optoelectronic, Aggregation, and Redox Properties of Double-Rotor Boron Difluoride Hydrazone Dyes

Daniela Cappello

Denis A.B. Therien

Viktor N. Staroverov

Francois Lagugne-Labarthet

Joe Gilroy

jgilroy5@uwo.ca

Follow this and additional works at: https://ir.lib.uwo.ca/chempub

Part of the Chemistry Commons

Citation of this paper:

Cappello, D.; Therien, D.A.B.; Staroverov, V.N.; Lagugné-Labarthet, F.; Gilroy, J.B.* “Optoelectronic, Aggregation, and Redox Properties of Double-Rotor Boron Difluoride Hydrazone Dyes” Chemistry - A European Journal 2019, 25, 5994-6006. 


\section{Optoelectronic, Aggregation, and Redox Properties of Double-Rotor Boron Difluoride Hydrazone Dyes}

Daniela Cappello, Denis A. B. Therien, Viktor N. Staroverov, François Lagugné-Labarthet, and Joe B. Gilroy*

Department of Chemistry and the Centre for Advanced Materials and Biomaterials Research (CAMBR), The University of Western Ontario, London, Ontario, N6A 5B7, Canada

\section{TOC GRAPHIC}
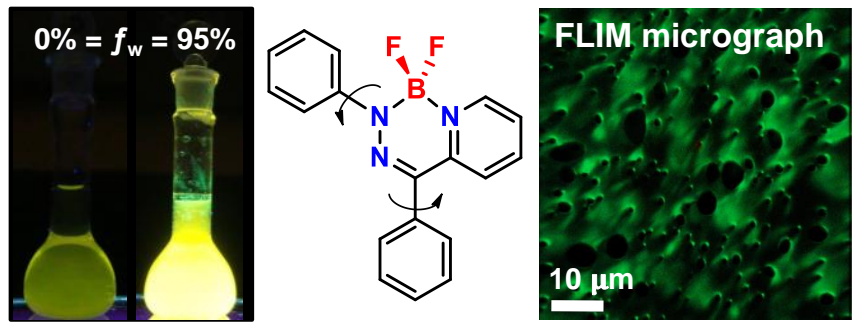

Daniela Cappello, D. Alex Therien, Viktor N. Staroverov, François LagugnéLabarthet and Joe B. Gilroy*

Page No. - Page No.

Optoelectronic, Aggregation, and Redox Properties of Double-Rotor Boron Difluoride Hydrazone Dyes

Double-rotor boron difluoride hydrazones possess tunable absorption and photoluminescence properties, support boratahydrazyl radicals, and exhibit strong aggregation-induced photoluminescence in thin films. 


\begin{abstract}
We develop the chemistry of boron difluoride hydrazone dyes (BODIHYs) bearing two aryl substituents and explore their properties. The low-energy absorption bands $\left(\lambda_{\max }=427-464 \mathrm{~nm}\right)$ of these dyes depend on the nature of the $N$-aryl groups appended to the BODIHY framework. Electron-donating and extended $\pi$-conjugated groups cause a red shift, whereas electronwithdrawing groups result in a blue shift. The title compounds were weakly photoluminescent in solution and strongly photoluminescent as thin films $\left(\lambda_{\mathrm{PL}}=525-578 \mathrm{~nm}\right)$ with quantum yields of up to $18 \%$ and lifetimes of 1.1-1.7 ns, consistent with the dominant radiative decay through fluorescence. Addition of water to THF solutions of the BODIHYs studied causes molecular aggregation which restricts intramolecular motion and thereby enhances photoluminescence. The observed photoluminescence of BODIHY thin films is likely facilitated by a similar molecular packing effect. Finally, cyclic voltammetry studies confirmed that BODIHY derivatives bearing para-substituted $N$-aryl groups could be reversibly oxidized $\left(E_{\mathrm{ox} 1}=0.62-1.02 \mathrm{~V} \mathrm{vs}\right.$. $\left.\mathrm{Fc} / \mathrm{Fc}^{+}\right)$to their radical cation forms. Chemical oxidation studies confirmed that para-substituents at the $\mathrm{N}$-aryl groups are required to circumvent radical decomposition pathways. Our findings provide new opportunities and guiding principles for the design of sought-after multifunctional boron difluoride complexes that are photoluminescent in the solid state.
\end{abstract}

\title{
KEYWORDS
}

Boron-Nitrogen Heterocycles; Solid-State Photoluminescence; Redox Chemistry; Radical Cations; Fluorescence-Lifetime Imaging Microscopy 


\section{INTRODUCTION}

The complexation of boron difluoride $\left(\mathrm{BF}_{2}\right)$ units by chelating $N$-donor ligands with delocalized $\pi$ electron systems is a common strategy for the production of photoluminescent dyes. ${ }^{[1]}$ The efficacy of this approach is due in part to the rigidification of the ligand backbone upon complexation and the tendency of the $\mathrm{BF}_{2}$ moiety to induce push-pull electronic effects conducive to strong photoluminescence (PL). This class of dyes, which includes compounds derived from dipyrrin (1, BODIPYs),${ }^{[2],[3]}$ aza-dipyrrin (2, aza-BODIPYs), ${ }^{[2],[3]}$ indigo- $N, N^{\prime}$-diarylimine $(\mathbf{3}),{ }^{[4]}$ anilido pyridine (4) ${ }^{[5]}$ bispyrrole $(\mathbf{5}$, BOPHYs $),{ }^{[6]}$ and formazanate $(\mathbf{6}){ }^{[7]}$ ligands, has been used extensively for biological imaging applications. ${ }^{[8],[9]}$ Despite their desirable intense PL, large Stokes shifts, and tunable properties, relatively few known $\mathrm{BF}_{2}$ complexes photoluminesce in the solid state, ${ }^{[10]} \mathrm{a}$ result of aggregation-caused quenching that is facilitated by their planar $\pi$-electron systems. ${ }^{[11]}$ In order to expand the use of such materials in applications that require solid-state PL (e.g., display technologies and solid-state sensors), it is imperative to develop new $\mathrm{BF}_{2}$ complexes of $\mathrm{N}$-donor ligands and to understand their optoelectronic properties.

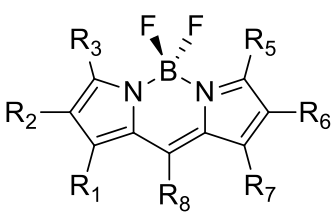

1

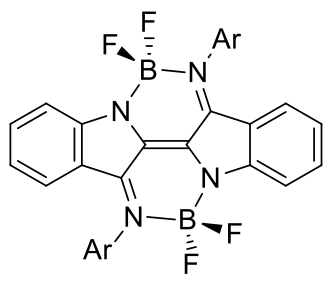

3

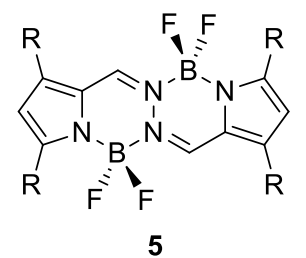

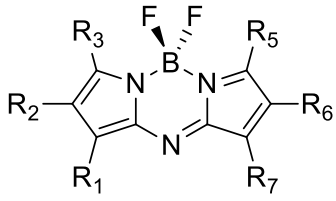

2

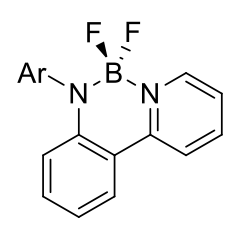

4

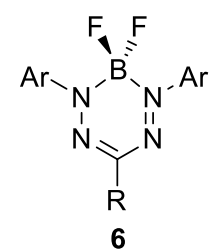

Pioneering work by Aprahamian and co-workers ${ }^{[12],[13]}$ has led to the discovery of $\mathrm{BF}_{2}$ complexes of hydrazones that adopt structures involving both five- (7) and six-membered (7', BODIHYs) chelate rings and have unique chemistry. For example, derivatives of 7 undergo 
trans/cis isomerization triggered by visible ${ }^{[13 \mathrm{a}]}$ and near-IR ${ }^{[13 \mathrm{c}]}$ light and by controlled aggregation. ${ }^{[13 \mathrm{e}]}$ Derivatives of $\mathbf{7}^{\prime}$ were also found to exhibit non-classical fluorescence upon relaxation from high-energy excited states in violation of Kasha's rule ${ }^{[13 \mathrm{~d}]}$ and undergo aggregationinduced emission leading to PL in the solid state. ${ }^{[13 \mathrm{~b}]}$ The latter properties originate from restricted intramolecular motion of the $N$-aryl substituent which hinders $\pi$-stacking interactions upon aggregation and often leads to aggregation-caused quenching. ${ }^{[1]}$
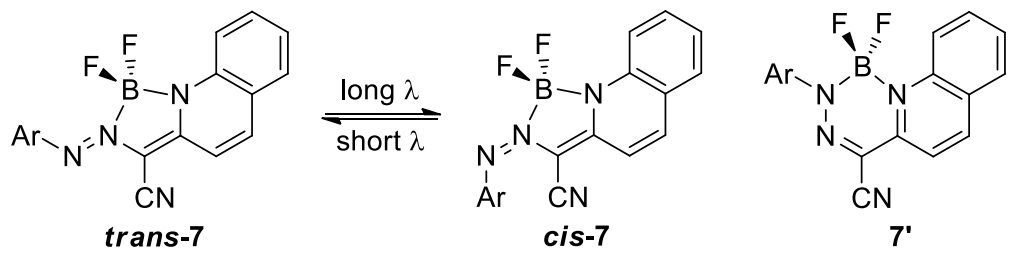

In this paper, we investigate the effect of a $C$-phenyl group on the optoelectronic, aggregation, and redox properties of BODIHYs. By appending a second aryl substituent to the BODIHY framework we create double molecular rotors that are capable of aggregation-induced emission and photoluminescence in the solid state, and have an extended $\pi$-electron system that can be potentially exploited to facilitate the stabilization of radicals.

\section{RESULTS AND DISCUSSION}

Synthesis and Characterization

Hydrazones 8a-8e were prepared by condensation reactions between aryl hydrazines and 2benzoylpyridine (Figures S1-S10). Hydrazone 9b was prepared by adapting a literature procedure involving a coupling reaction between toluenediazonium chloride and 2-pyridylacetonitrile (Figures S11-12). ${ }^{[13 \mathrm{~d}]}$ The ${ }^{1} \mathrm{H}$ NMR spectra for these compounds were consistent with their low symmetry and existence as single isomers. Diagonostic NH resonances were observed between 9.11 and $10.26 \mathrm{ppm}$ for $\mathbf{8 a}-\mathbf{8 e}$ and $14.97 \mathrm{ppm}$ for $\mathbf{9 b}$. The hydrazones were converted to their corresponding $\mathrm{BF}_{2}$ complexes (BODIHYs) 10a-10e and $\mathbf{1 1 b}$ by heating them in toluene in the presence of excess $\mathrm{BF}_{3} \cdot \mathrm{OEt}_{2}$ and $\mathrm{NEt}_{3}$ in yields of $51-92 \%$ that were largely dependent on the ease of purification for each compound (Scheme 1). These compounds were characterized using ${ }^{1} \mathrm{H},{ }^{11} \mathrm{~B},{ }^{13} \mathrm{C}\left\{{ }^{1} \mathrm{H}\right\}$, and ${ }^{19} \mathrm{~F}$ NMR spectroscopy, IR and UV-vis absorption and PL spectroscopy, and mass spectrometry 
(Figures S13-S26). The ${ }^{1} \mathrm{H}$ NMR spectra for the purified BODIHY compounds were also consistent with the proposed structures and lacked the $\mathrm{NH}$ resonances observed for the parent hydrazones. Their ${ }^{11} \mathrm{~B}$ and ${ }^{19} \mathrm{~F}$ NMR spectra revealed characteristic triplets between 0.2 and $0.7 \mathrm{ppm}$ and quartets between -133.8 and $-138.9 \mathrm{ppm}$, respectively. These data confirm the presence of four coordinate boron atoms bound to two nitrogen atoms and two fluorine atoms.

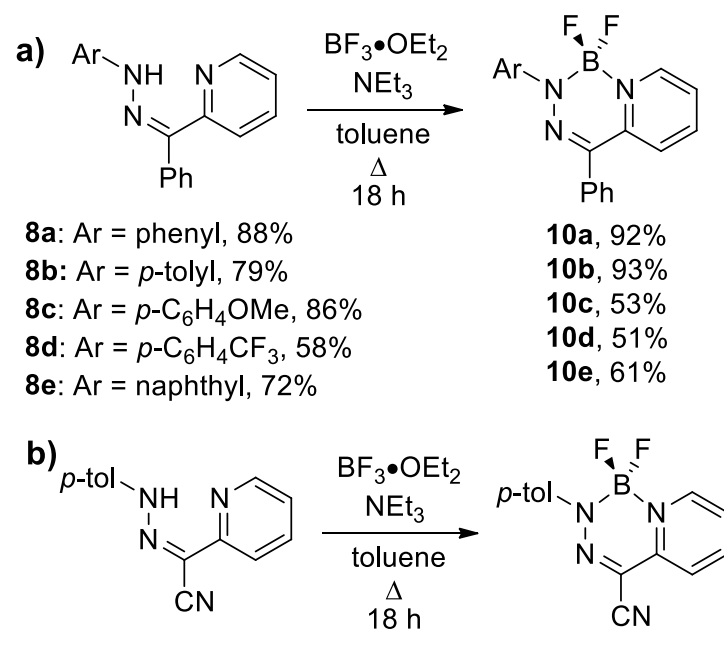

Scheme 1. Syntheses of BODIHYs 10a-10e and $\mathbf{1 1 b .}$

\section{$X$-ray Crystallography}

Single-crystal X-ray diffraction experiments (Figure 1, Tables 1 and S1) produced the solid-state structures of $\mathbf{1 0 a}, \mathbf{1 0 b}$, and $\mathbf{1 0 d}$ that revealed several important features. The BODIHY (N1-N2-C1C2-N3) backbone possessed a delocalized $\pi$-electron system, as evidenced by the average N1-N2

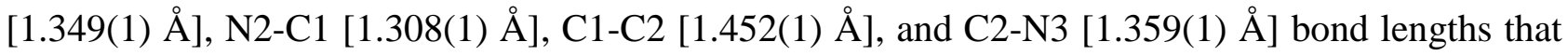
were intermediate between those typically expected for single and double bonds of the respective atoms. $^{[14]}$ Further inspection of the structures revealed that the B1 atom was displaced by $0.3795(19) \AA$ (10a), 0.367(2) $\AA$ (10b), and 0.499(4) $\AA$ (10d) from the plane defined by the N1, N2, C2, C2, N3 atoms. The $N$-aryl $\left[32.10(6)-40.21(6)^{\circ}\right]$ and $C$-phenyl [44.89(5)-57.79(4) $)^{\circ}$ groups are twisted substantially relative to the same plane. The structural metrics observed did not change significantly when the para-substituents at the $N$-aryl rings were altered. 

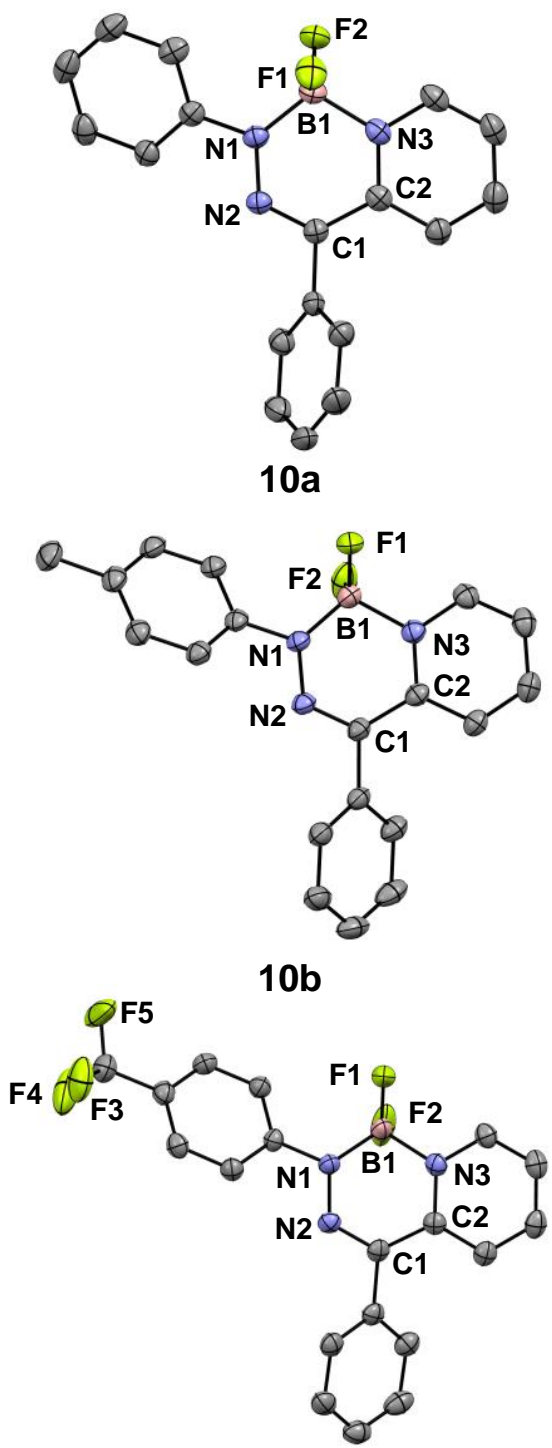

10d

Figure 1. Solid-state structures of BODIHYs 10a, 10b, and 10d. Anisotropic displacement ellipsoids are shown at the $50 \%$ probability level and hydrogen atoms are omitted for clarity. The $\mathrm{CF}_{3}$ group of 10d was disordered. For clarity, the dominant conformer [82.7(4)\%] is shown. 
Table 1. Selected bond lengths $(\AA)$, angles $\left(^{\circ}\right)$, and other metrics for $\mathrm{BF}_{2}$ hydrazonate complexes 10a, 10b, and 10d.

\begin{tabular}{|c|c|c|c|}
\hline & 10a & 10b & 10d \\
\hline N1-N2 & $1.347(1)$ & $1.344(2)$ & $1.356(2)$ \\
\hline $\mathrm{N} 2-\mathrm{C} 1$ & $1.305(2)$ & $1.312(2)$ & $1.306(3)$ \\
\hline $\mathrm{C} 1-\mathrm{C} 2$ & $1.451(2)$ & $1.450(2)$ & $1.455(3)$ \\
\hline $\mathrm{C} 2-\mathrm{N} 3$ & $1.358(2)$ & $1.358(2)$ & $1.361(3)$ \\
\hline N3-B1 & $1.578(2)$ & $1.580(2)$ & $1.571(4)$ \\
\hline N1-B1 & $1.522(2)$ & $1.517(2)$ & $1.516(3)$ \\
\hline N1-B1-N3 & $107.0(1)$ & $106.6(1)$ & $106.3(2)$ \\
\hline $\mathrm{B} 1-\mathrm{N} 1-\mathrm{N} 2$ & $123.2(1)$ & $123.9(1)$ & $121.2(2)$ \\
\hline $\mathrm{C} 2-\mathrm{N} 3-\mathrm{B} 1$ & $121.4(1)$ & $121.8(1)$ & $120.2(2)$ \\
\hline $\mathrm{N} 2-\mathrm{C} 1-\mathrm{C} 2$ & $124.3(1)$ & $123.5(1)$ & $123.7(2)$ \\
\hline Boron displacement $^{[\mathrm{a}]}$ & $0.3795(19)$ & $0.367(2)$ & $0.499(4)$ \\
\hline Dihedral angles, $N$-aryl substituent ${ }^{[\mathrm{b}]}$ & $32.10(6)$ & $40.21(6)$ & $37.2(1)$ \\
\hline Dihedral angles, $C$-phenyl substituent ${ }^{[\mathrm{c}]}$ & $57.79(4)$ & $44.89(5)$ & $45.27(8)$ \\
\hline
\end{tabular}

${ }^{[a]}$ Distance between B1 and the plane defined by N1,N2,C1,C2,N3. ${ }^{[b]}$ Dihedral angle between the plane defined by $\mathrm{N} 1, \mathrm{~N} 2, \mathrm{C} 1, \mathrm{C} 2, \mathrm{~N} 3$ and the plane defined by the $N$-aryl substituent. ${ }^{[\mathrm{c}]}$ Dihedral angle between the plane defined by N1,N2,C1,C2,N3 and the plane defined by the $C$-phenyl substituent.

\section{Electronic Structure and Properties}

The electronic structure of BODIHYs 10a-10e was investigated experimentally using UV-vis absorption and PL spectroscopy and computationally using density functional theory (DFT). As we are primarily concerned with optoelectronic properties of BODIHY dyes in the visible region, our discussion will focus on the lowest energy bands for each complex (Figures 2 and S26, Table 2). Substituent effects will be discussed relative to BODIHY 10a $(\mathrm{Ar}=$ phenyl $)$.

In $\mathrm{CH}_{2} \mathrm{Cl}_{2}$, the absorption maxima ( $\lambda_{\max }$ ) observed for BODIHYs with $N$-aryl groups bearing electron-donating para-substituents were red-shifted relative to the absorption maximum of $\mathbf{1 0 a}$ $\left(\lambda_{\max }=436 \mathrm{~nm}\right)$ : for 10b $(\mathrm{Ar}=p$-tolyl $), \Delta \lambda_{\max }=10 \mathrm{~nm}$; for 10c $\left(\mathrm{Ar}=p-\mathrm{C}_{6} \mathrm{H}_{4} \mathrm{OMe}\right), \Delta \lambda_{\max }=19 \mathrm{~nm}$. A modest blue shift was observed when an electron-withdrawing $p-\mathrm{C}_{6} \mathrm{H}_{4} \mathrm{CF}_{3} N$-aryl substituent was introduced (10d, $\left.\Delta \lambda_{\max }=-4 \mathrm{~nm}\right)$. Extending the size of the $\pi$-electron system by incorporating a naphthyl substituent at nitrogen also resulted in a red shift (10e, $\left.\Delta \lambda_{\max }=15 \mathrm{~nm}\right)$. Similar trends were observed for the spectra collected in THF and toluene. The spectra collected for thin films of 10a-10e were generally red-shifted relative to those collected in solution (Figure 2b). Compared to BODIHYs bearing cyano substituents at carbon $\left(7^{\prime}\right),{ }^{[13 \mathrm{~b}, 13 \mathrm{~d}]}$ the low-energy absorption maxima observed for 10a-10e were red-shifted as a result of the extended $\pi$-electron delocalization involving the $C$-phenyl group. However, all of the absorption maxima were blue-shifted relative to those of structurally-related $\mathrm{BF}_{2}$ formazanate complexes $(\mathbf{6})$ in which the heterocyclic framework includes an additional nitrogen atom. ${ }^{[15]}$ 

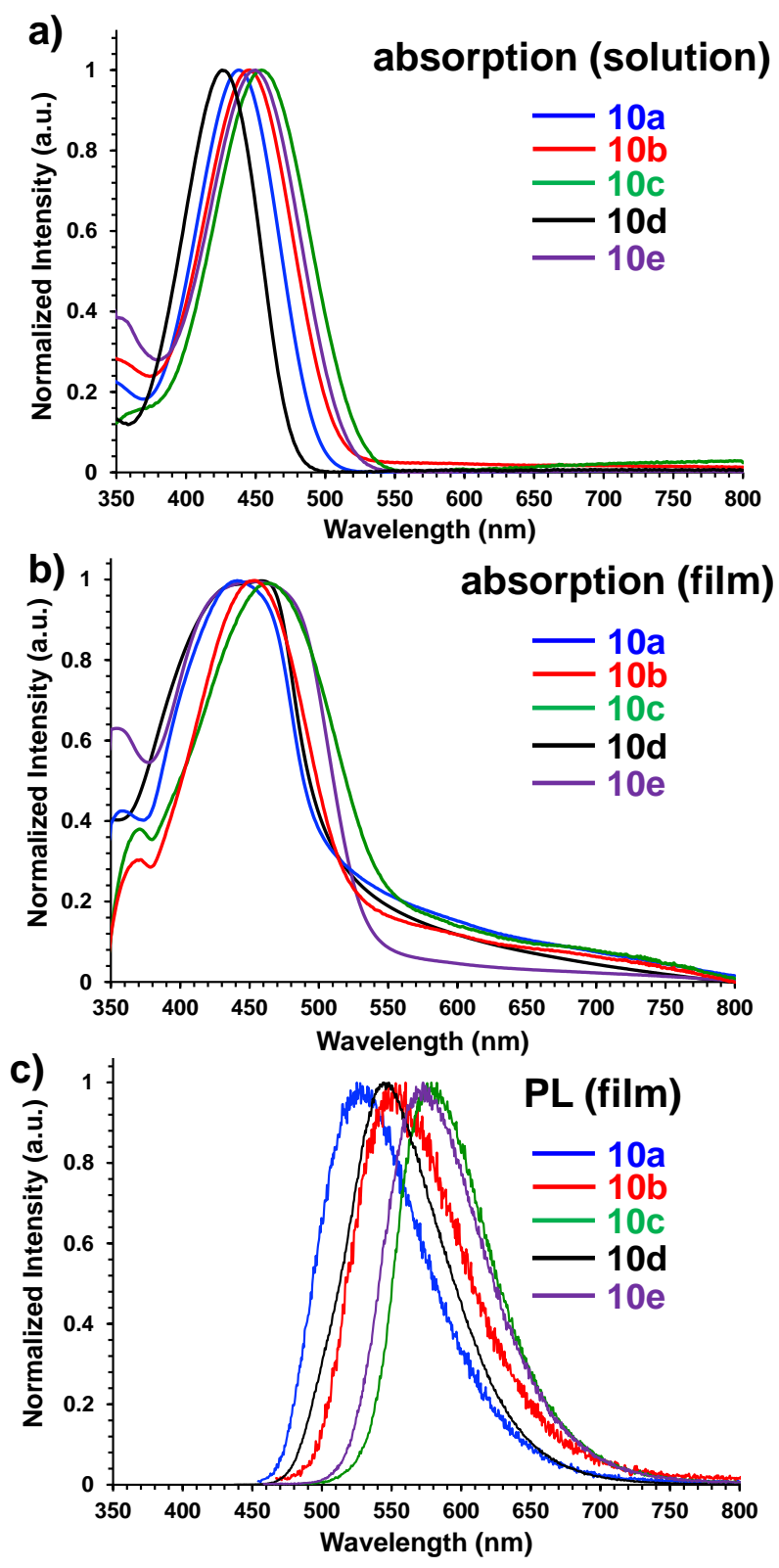

Figure 2. UV-Vis absorption spectra of $\mathbf{1 0 a}-\mathbf{1 0 e}$ (a) ca. $3.5 \mu \mathrm{M}$ solutions in $\mathrm{CH}_{2} \mathrm{Cl}_{2}$ and (b) thin films. (c) PL spectra collected for the thin films of 10a-10e.

The observed UV-vis spectra and substituent effects as discussed above were well reproduced by adiabatic linear-response time-dependent DFT (TDDFT) calculations for the three representative structures: 10a, 10c, and 10d (Table S2 and Figure S27). The dominant orbital pairs implicated in the three lowest-energy transitions, in order of increasing energy, were as follows: the highest occupied molecular orbital (HOMO) and the lowest unoccupied molecular orbital (LUMO), 
HOMO and LUMO+1, and HOMO and LUMO+2 (Figures 3 and S28-S29). The HOMO and LUMO are delocalized $\pi$-orbitals, which suggests that the lowest-energy transitions are of $\pi \rightarrow \pi^{*}$ type.

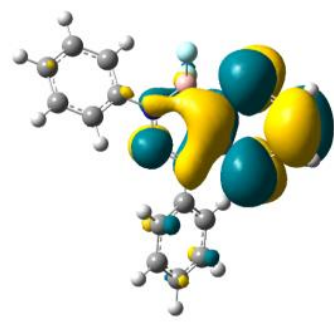

LUMO+1

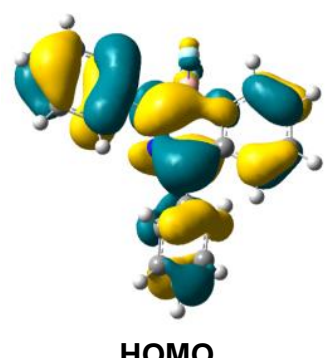

номо

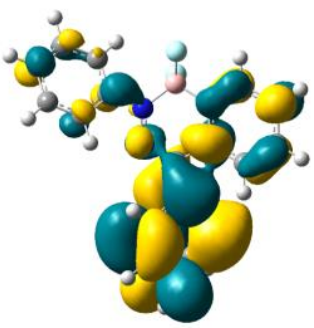

LUMO+2

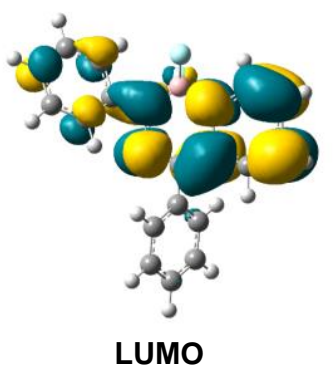

Figure 3. Molecular orbitals of compound 10a.

In solution, BODIHYs 10a-10e exhibited very weak PL, likely as a result of intramolecular motion associated with the $N$-aryl and $C$-phenyl rotors (Figure S30, Table 2). The PL maxima $\left(\lambda_{\mathrm{PL}}\right)$ followed trends similar to those observed in the corresponding absorbance spectra. Thin films of 10a-10e were photoluminescent, likely due to restricted intramolecular motion associated with aggregation, with $\lambda_{\mathrm{PL}}$ values ranging from 525 to $578 \mathrm{~nm}$, Stokes shifts $\left(v_{\mathrm{ST}}\right)$ of 81-124 nm (3475$5171 \mathrm{~cm}^{-1}$ ) and quantum yields $\left(\Phi_{\mathrm{PL}}\right)$ of up to $18 \%$ (Figure $2 \mathrm{c}$, Table 2 ) that were comparable to the

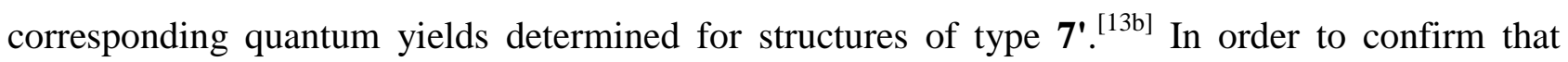
restricted intramolecular motion rather than intermolecular interactions was the likely origin of the PL enhancement, we prepared poly(methyl methacrylate) films doped with 1\% BODIHY (by mass) and showed that they also exhibit intense PL (Figure S31, Table S3). No distinct trend in the thin film $\lambda_{\text {PL }}$ data was observed, indicating that the structures of BODIHYs 10a-10e in the solid state may heavily influence $\lambda_{\mathrm{PL}}$. 
Table 2. UV-Vis absorption and emission data for BODIHYs 10a-10e. ${ }^{[\mathrm{a}-\mathrm{d}]}$

\begin{tabular}{|c|c|c|c|c|c|c|c|}
\hline & $\lambda_{\max }(\mathrm{nm})$ & $\varepsilon\left(\mathrm{M}^{-1} \mathrm{~cm}^{-1}\right)$ & $\lambda_{\mathrm{PL}}(\mathbf{n m})$ & $\Phi_{P L}(\%)$ & $\mathrm{v}_{\mathrm{ST}}(\mathrm{nm})$ & $v_{\mathrm{ST}}\left(\mathrm{cm}^{-1}\right)$ & $\tau(\mathbf{n s})^{[\mathrm{e}]}$ \\
\hline \multicolumn{8}{|l|}{ 10a, $\mathrm{Ar}=$ phenyl } \\
\hline THF solution & 437 & 20100 & 547 & $<1$ & 110 & 4602 & - \\
\hline $\mathrm{CH}_{2} \mathrm{Cl}_{2}$ solution & 437 & 13200 & 540 & $<1$ & 103 & 4365 & - \\
\hline Toluene solution & 447 & 11600 & 542 & $<1$ & 95 & 3921 & - \\
\hline Aggregates & 454 & - & 567 & - & 113 & 4390 & - \\
\hline Thin film & 444 & - & 525 & 18 & 81 & 3475 & 1.2 \\
\hline \multicolumn{8}{|l|}{ 10b, $\mathrm{Ar}=p$-tolyl } \\
\hline THF solution & 445 & 19900 & 550 & $<1$ & 105 & 4290 & - \\
\hline $\mathrm{CH}_{2} \mathrm{Cl}_{2}$ solution & 446 & 18400 & 565 & $<1$ & 119 & 4722 & - \\
\hline Toluene solution & 455 & 13000 & 556 & $<1$ & 101 & 3991 & - \\
\hline Aggregates & 460 & - & 556 & - & 96 & 3754 & - \\
\hline Thin film & 457 & - & 568 & 5 & 111 & 4276 & 1.1 \\
\hline \multicolumn{8}{|c|}{ 10c, $\mathrm{Ar}=p-\mathrm{C}_{6} \mathrm{H}_{4} \mathrm{OMe}$} \\
\hline THF solution & 454 & 13700 & 577 & $<1$ & 123 & 4695 & - \\
\hline $\mathrm{CH}_{2} \mathrm{Cl}_{2}$ solution & 453 & 22200 & 576 & $<1$ & 123 & 4714 & - \\
\hline Toluene solution & 464 & 11000 & 578 & $<1$ & 114 & 4251 & - \\
\hline Aggregates & 462 & - & 579 & - & 117 & 4374 & - \\
\hline Thin film & 475 & - & 578 & 1 & 103 & 3751 & 1.7 \\
\hline \multicolumn{8}{|c|}{ 10d, $\mathrm{Ar}=p-\mathrm{C}_{6} \mathrm{H}_{4} \mathrm{CF}_{3}$} \\
\hline THF solution & 428 & 16200 & 517 & 1 & 89 & 4022 & - \\
\hline $\mathrm{CH}_{2} \mathrm{Cl}_{2}$ solution & 432 & 25700 & 521 & $<1$ & 89 & 3954 & - \\
\hline Toluene solution & 440 & 21800 & 521 & 1 & 81 & 3533 & - \\
\hline Aggregates & 434 & - & 527 & - & 93 & 4066 & - \\
\hline Thin film & 427 & - & 548 & 13 & 121 & 5171 & 1.3 \\
\hline \multicolumn{8}{|l|}{ 10e, $\mathrm{Ar}=$ naphthyl } \\
\hline THF solution & 450 & 16900 & 561 & 5 & 111 & 4397 & - \\
\hline $\mathrm{CH}_{2} \mathrm{Cl}_{2}$ solution & 451 & 13600 & 571 & 5 & 120 & 4660 & - \\
\hline Toluene solution & 461 & 15100 & 572 & 5 & 111 & 4209 & - \\
\hline Aggregates & 455 & - & 567 & - & 112 & 4342 & - \\
\hline Thin film & 448 & - & 572 & 5 & 124 & 4839 & 1.4 \\
\hline
\end{tabular}

Fluorescence-lifetime imaging microscopy (FLIM) was used to further study thin films of BODIHYs 10a-10e (Figures 4, S32-S33 and Table 2). The resulting thin films with typical thicknesses of $c a$. $0.5 \mu \mathrm{m}$ were inhomogenous due to the presence of bubbles created during the spin-coating procedure due to solvent evaporation. The Swiss-cheese-like structures show a distribution of holes with dimensions varying from 1 to $5 \mu \mathrm{m}$ (Figure 4). It should also be noted that defect-heavy regions of the films were intentionally imaged to ensure appropriate image contrast and focus. These data show that the PL lifetimes $(\tau)$ have little dependence on the morphological features of the films, as edge and solid portions of the film exhibited very similar lifetimes. For 
films of 10a-10e, the lifetimes of the major PL intensity decay ranged from $\tau=1.1$ to $1.7 \mathrm{~ns}$, confirming that the dominant PL mechanism is fluorescence. These average lifetimes were analyzed by fitting the fluorescence decay of each point of the resulting fluorescence image with the exclusion of the hollow bubble-like regions. The thin-film lifetimes measured in this study are approximately an order of magnitude greater than those observed for viscous solutions of related BODIHYs $\left(\mathbf{7}^{\prime}\right){ }^{[13 \mathrm{~d}]}$
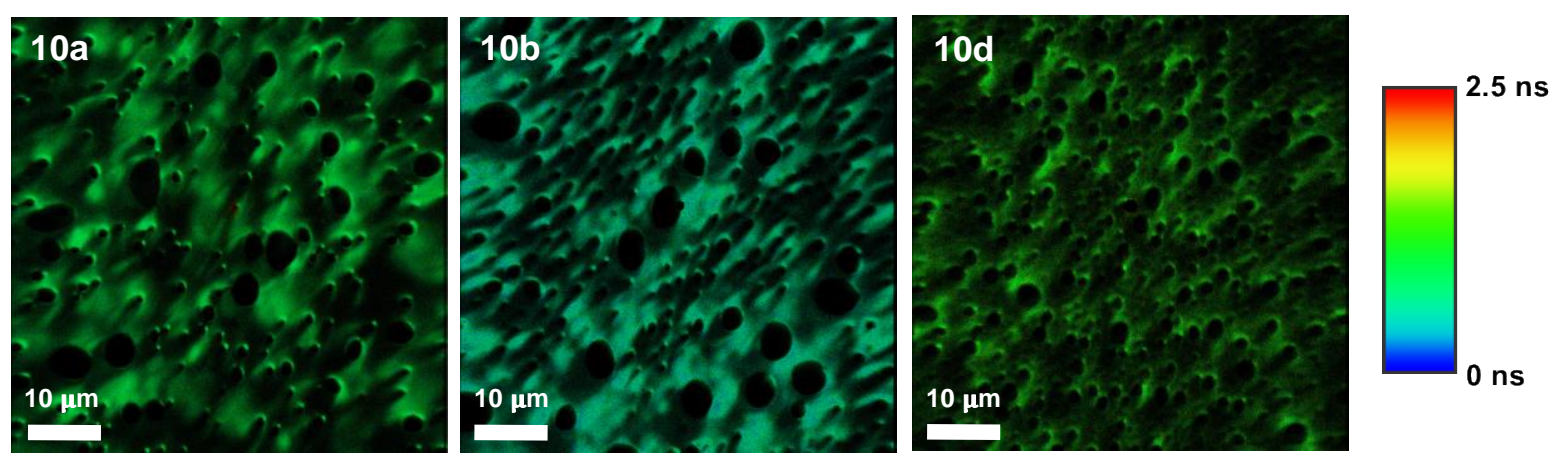

Figure 4. FLIM micrographs showing lifetime distributions for thin films of $\mathbf{1 0 a}, \mathbf{1 0 b}$, and $\mathbf{1 0 d}$.

\section{Aggregation Studies}

Given the weak PL in solution and appreciable PL of thin films of 10a-10e, we examined their solution-phase aggregation behavior. Triplicate analysis of the PL spectra of $200 \mu \mathrm{M}$ solutions of each compound in THF containing varying quantities of deionized water revealed several trends (Figures 5 and S34, Table 2). Significant PL enhancement was observed at a critical water volume fraction $\left(f_{\mathrm{w}}\right)$ of $75 \%$ for $\mathbf{1 0 a}, \mathbf{1 0 b}, \mathbf{1 0 d}$, and $10 \mathbf{e}$ and $80 \%$ for $10 \mathbf{c}$, at which point aggregation of the dyes likely leads to restricted intramolecular motion. Inspection of the solid-state packing in the structures obtained for $\mathbf{1 0 a}, \mathbf{1 0 b}$, and $\mathbf{1 0 d}$ revealed short intermolecular $\mathrm{CH} \bullet \pi($ ca. 3.0-3.1 $\AA$ ), $\mathrm{CH} \bullet \mathrm{N}(c a .2 .9-3.3 \AA)$, and $\mathrm{CH} \bullet \cdot \mathrm{F}(c a .2 .4-3.0 \AA)$ contacts that likely restrict intramolecular motion (Figures S35-37). The degree of enhancement was quantified by using the ratio of the integrated PL intensities for solutions with $f_{\mathrm{w}}=95 \%$ and $0 \%$; the resulting enhancement factors were 123 for 10a, 30 for 10b, 11 for 10c, 65 for 10d, and 35 for 10e. The trends in PL enhancement mirrored the trends in $\Phi_{\mathrm{PL}}$ values observed for thin films of the same compounds.

Upon the initial addition of water, the PL maxima observed for each compound blue-shifted and the PL intensity remained relatively constant. This behavior is consistent with the ground states 
of 10a-10e having greater polarity than the excited states involved, where an increase in solvent polarity would widen the energy gap between the excited and ground states. We rule out twisted intermolecular charge transfer on the basis that red-shifted PL maxima would normally be expected when such a mechanism is operative. ${ }^{[16]}$ In the case of compounds $\mathbf{1 0 a}, \mathbf{1 0 b}$, and $\mathbf{1 0 e}$, the onset of PL enhancement coincided with a gradual red shift in $\lambda_{\mathrm{PL}}$ that was consistent with decreased polarity in the aggregates formed relative to the THF:water solution and/or the formation of Jaggregates. ${ }^{[17]}$ In the solid state, intermolecular $\pi$-type interactions were observed for compounds 10a, 10b, and 10d and may support the latter conclusion, although it should be noted that the intermolecular contact distances (ca. 4.6-5.6 $\AA$ ) are larger than would be expected for normal $\pi-\pi$ stacking interactions. Solutions of $\mathbf{1 0 d}$ behaved similarly, although the red shift in $\lambda_{\mathrm{PL}}$ was observed at significantly lower $f_{\mathrm{w}}$ values. Conversely, $\lambda_{\mathrm{PL}}$ values obtained for 10c consistently blue-shifted with increasing $f_{\mathrm{w}}$ values. Our inability to obtain a solid-state structure for this compound precluded a detailed investigation of this behavior, but the PL data collected may imply the formation of $\mathrm{H}$-aggregates.

Thus, the aggregation studies support our conclusion that restricted intramolecular motion is the dominant factor leading to PL in thin films and that appreciable PL enhancement is observed for readily accessible BODIHYs $\mathbf{1 0 a - 1 0 e}$ despite their double-rotor structure. 

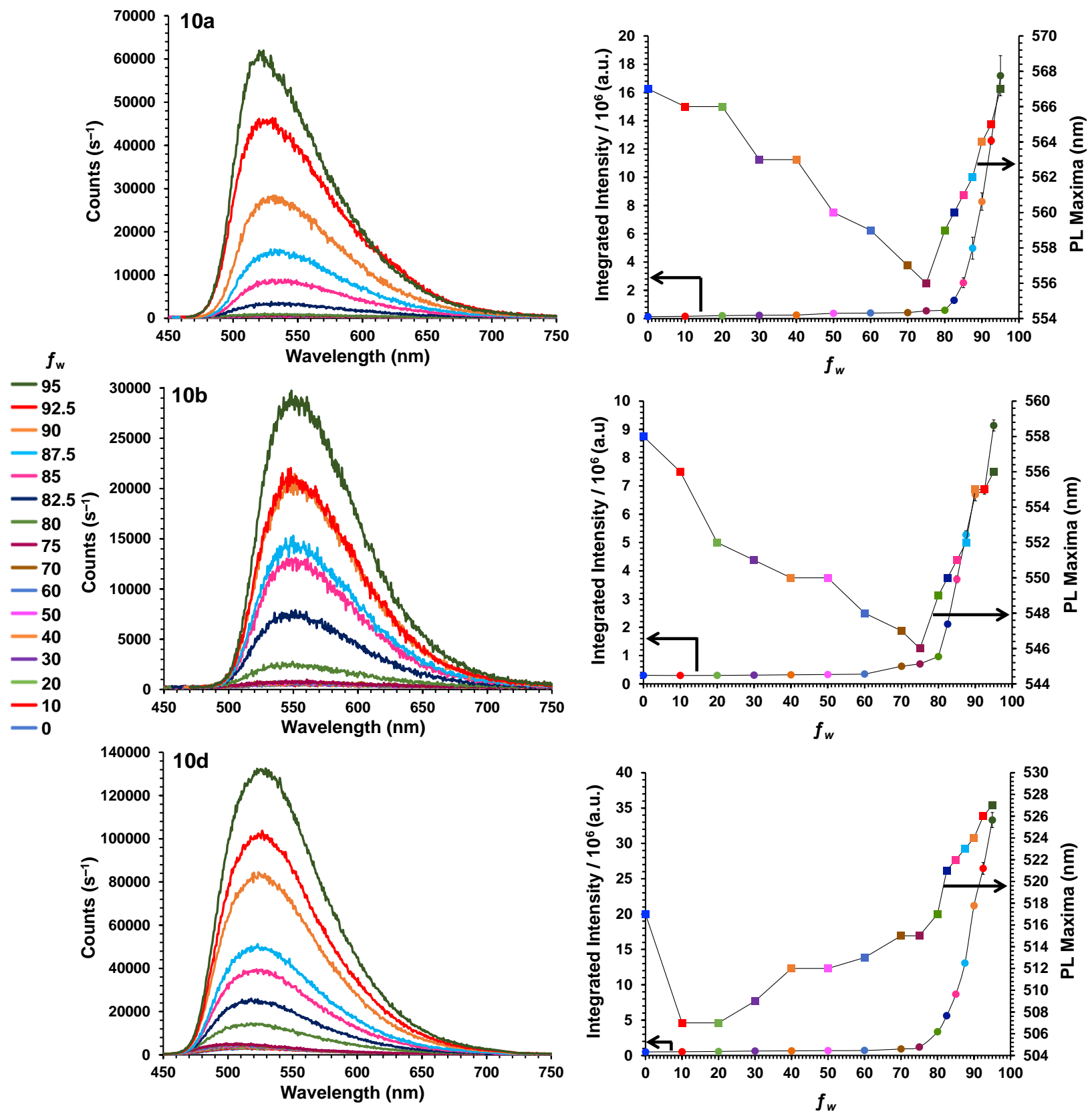

Figure 5. Left: PL spectra for compounds 10a, 10b, and 10d plotted as a function of $f_{\mathrm{w}}$ in THF. Right: Integrated PL intensity (circles) and wavelength of maximum PL intensity (squares) as a function of $f_{\mathrm{w}}$ in THF. Concentrations were held constant at $200 \mu \mathrm{M}$. The integrated intensities and error bars originate from the average of three independent experiments.

\section{Redox Properties}

To the best of our knowledge, the redox properties of BODIHY dyes have not been investigated to date, prompting us to probe 10a-10e using cyclic voltammetry (Figure 6, Table 3). In doing so, we hoped to discover oxidative chemistry that may lead to stable radicals supported by the delocalized BODIHY heterocyclic backbone. Such species are of fundamental interest for their unique structure 
and bonding and have potential application in areas such as redox sensing, catalysis, and molecular magnetism. ${ }^{[18]}$ All of the title compounds were irreversibly reduced at potentials of $c a$. $-1.80 \mathrm{~V}$ relative to the ferrocene/ferrocenium redox couple with little dependence on the nature of the $N$-aryl groups. This observation was consistent with the relatively low LUMO density on the $N$-aryl rings (Figures 3 and S28-S29). On scanning to positive potentials, oxidative events were also observed and the potentials associated with these events tracked well with the electronics of the $N$-aryl groups. That is, BODIHYs with electron-rich $N$-aryl groups $(\mathbf{1 0 b}$ and $\mathbf{1 0 c})$ were easier to oxidize than $\mathbf{1 0 a}$, whereas complex 10d, which contains a $p-\mathrm{C}_{6} \mathrm{H}_{4} \mathrm{CF}_{3}$ substituent, was more difficult to oxidize than 10a. In the case of $\mathbf{1 0 c}$, a second oxidation wave was observed within the electrochemical window afforded by $\mathrm{CH}_{3} \mathrm{CN}$. More interesting is the fact that BODIHYs with $p$-substituted $N$-aryl rings (i.e., 10b, 10c, and 10d) exhibited reversible one-electron oxidation waves, while 'unsubstituted' compounds 10a and 10e exhibited irreversible, multielectron oxidation waves. Examination of the singly-occupied molecular orbitals (SOMOs) calculated for compounds 10a and 10c (Figure 7) revealed significant unpaired electron density at both the $N$-aryl and $C$-phenyl groups, but the electrochemical data imply that the unpaired electron density at the para-carbon of the $\mathrm{N}$-aryl substituent is leading to the reactivity observed, likely as a result of radical-radical coupling (i.e., dimerization). Similar trends in reactivity have been observed for triphenylmethyl radicals ${ }^{[19]}$ and phenalenyl radicals, ${ }^{[20]}$ whereby judicious substitution at sites of significant spin density circumvents radical decomposition. The cyclic voltammogram of BODIHY 11b was collected for comparison (Figure S38), revealing an irreversible oxidation at $1.20 \mathrm{~V}$ that confirmed that the $C$ phenyl substituent plays an important role in the stabilization of the radical cations generated upon oxidation, likely due to enhanced resonance delocalization. 


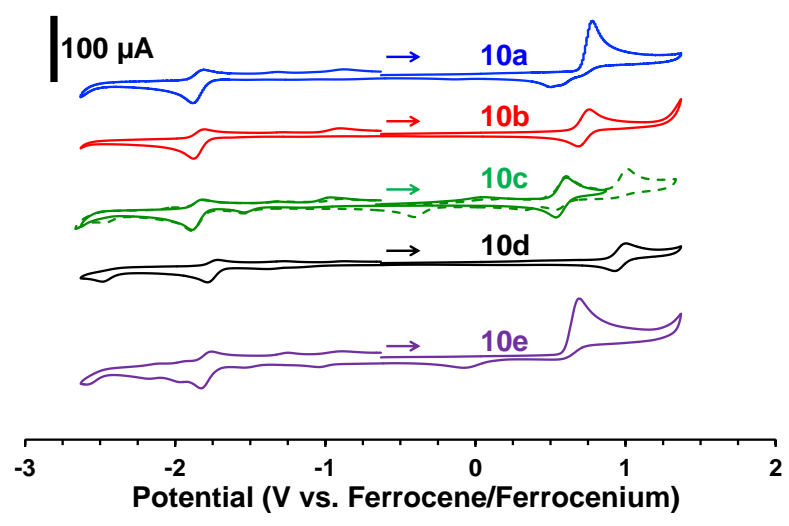

Figure 6. Cyclic voltammograms of BODIHYs 10a-10e recorded for dry, degassed $\mathrm{CH}_{3} \mathrm{CN}$ solutions containing $\sim 1 \mathrm{mM}$ analyte and $0.1 \mathrm{M}\left[n \mathrm{Bu}_{4} \mathrm{~N}\right]\left[\mathrm{PF}_{6}\right]$ as the supporting electrolyte at a scan rate of $250 \mathrm{mV} \mathrm{s}^{-1}$. Arrows denote the scan direction. The dashed line for 10c represents a wider potential scan window and revealed a second oxidation process.

Table 3. Electrochemical data for complexes 10a-10e. ${ }^{[\mathrm{a}]}$

\begin{tabular}{llcl}
\hline & $\boldsymbol{E}_{\text {red1 }}(\mathbf{V})$ & $\boldsymbol{E}_{\text {ox1 }}(\mathbf{V})$ & $\boldsymbol{E}_{\text {ox } 2}(\mathbf{V})$ \\
\hline $\mathbf{1 0 a}$ & $-1.85^{[\mathrm{b}]}$ & $0.79^{[\mathrm{c}]}$ & - \\
$\mathbf{1 0 b}$ & $-1.85^{[\mathrm{b}]}$ & 0.76 & - \\
$\mathbf{1 0 c}$ & $-1.85^{[\mathrm{b}]}$ & 0.62 & $1.06^{[\mathrm{cc}]}$ \\
$\mathbf{1 0 d}$ & $-1.75^{[\mathrm{b}]}$ & 1.02 & - \\
$\mathbf{1 0 e}$ & $-1.80^{[\mathrm{b}]}$ & $0.69^{[\mathrm{c}]}$ & - \\
$\mathbf{1 1 b}$ & -1.55 & $1.20^{[\mathrm{cc}]}$ & \\
\hline
\end{tabular}

${ }^{[a]}$ Cyclic voltammetry experiments were conducted for dry, degassed $\mathrm{CH}_{3} \mathrm{CN}$ solutions containing $1 \mathrm{mM}$ analyte and $0.1 \mathrm{M}\left[n \mathrm{Bu}_{4} \mathrm{~N}\right]\left[\mathrm{PF}_{6}\right]$ as the supporting electrolyte at a scan rate of $250 \mathrm{mV} \mathrm{s}{ }^{-1}$. All voltammograms were referenced internally against the ferrocene/ferrocenium redox couple. ${ }^{[\mathrm{b}]}$ Irreversible process, potential at maximum cathodic current reported. ${ }^{[\mathrm{cc}}$ Irreversible processes, potential at maximum anodic current reported.

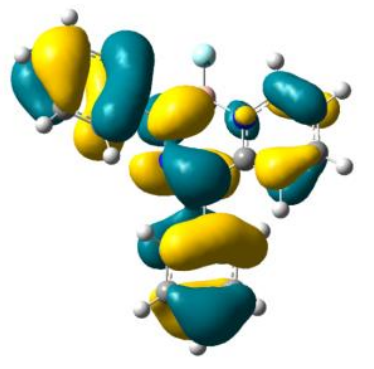

$10 a^{*+}$

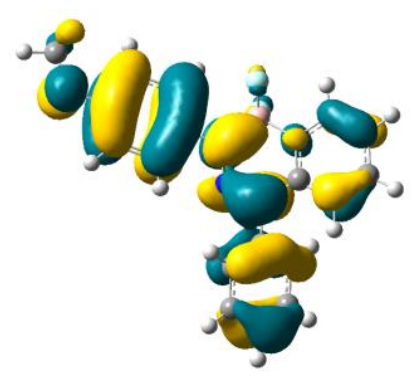

$10 c^{*+}$

Figure 7. SOMOs of compound $10 \mathbf{a}^{\cdot+}$ and $10 \mathbf{c}^{\bullet+}$. 
Finally, we explored chemical oxidation reactions of 10a, 10c, and 10e. Because BODIHY 10c was the easiest to oxidize electrochemically, we assumed that its oxidation was most likely to yield an isolable radical cation. Chemical oxidation of $\mathbf{1 0 c}$ produced radical cation $\mathbf{1 0 \mathbf { c } ^ { + + }}$ as a deep maroon/purple solid in $84 \%$ yield (Scheme 2). Radical $\mathbf{1 0 c ^ { + + }}$ was persistent enough in solution to allow for its characterization and represents the first open-shell species derived from BODIHYs. Solutions of $10 \mathbf{c}^{-+}$in $\mathrm{CH}_{2} \mathrm{Cl}_{2}$ yielded a broad, isotropic electron paramagnetic resonance (EPR) spectroscopy signal ( $g=2.0031$, Figure S39) and UV-vis absorption spectra that differed drastically from 10c (Figure 8). Specifically, two relatively weak absorption maxima at 777 and $703 \mathrm{~nm}$ appeared in the absorption spectrum of $\mathbf{1 0 c ^ { - + }}$ and the intense absorption of 10c centered at $453 \mathrm{~nm}$ disappeared. Both the EPR and UV-vis absorption spectra are consistent with those observed for related boron adducts of redox-active formazanate ligands. ${ }^{[7 \mathrm{a}, 21]}$

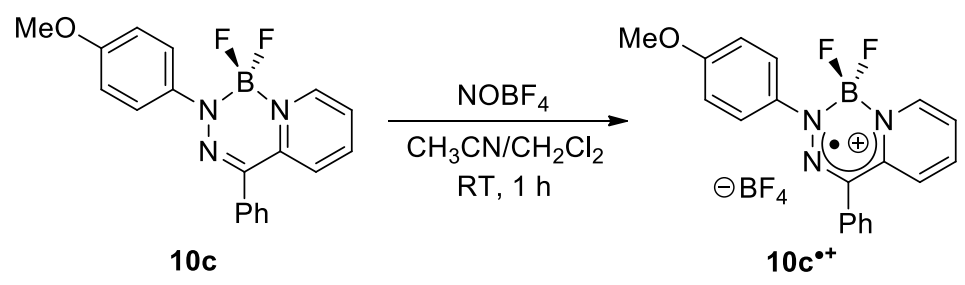

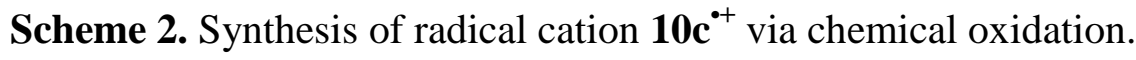

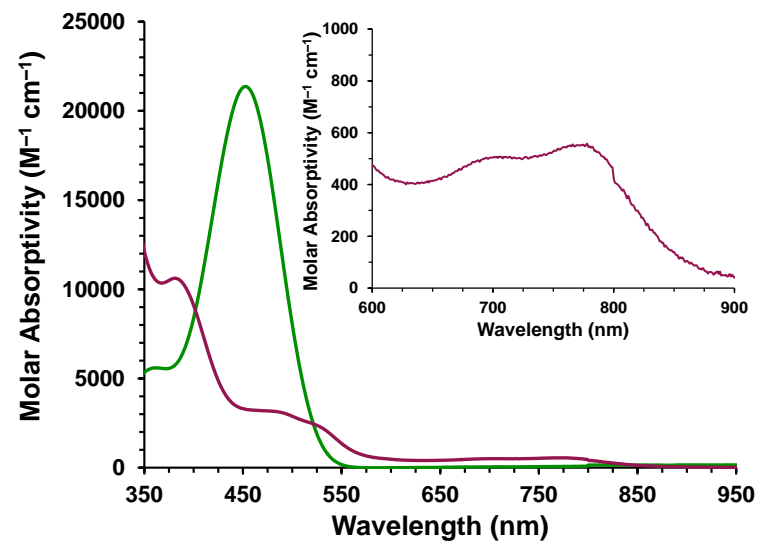

Figure 8. (a) UV-vis absorption spectra of $10 \mathrm{c}$ and $10 \mathrm{c}^{\bullet+}$ collected for $c a .3 \mu \mathrm{M}$ solutions in dry, degassed $\mathrm{CH}_{2} \mathrm{Cl}_{2}$. The inset is an expansion of the low-energy region of the spectrum of $\mathbf{1 0 c ^ { \bullet + }}$. 
The chemical oxidation of BODIHYs $\mathbf{1 0 a}$ and $\mathbf{1 0 e}$ with $\mathrm{NOBF}_{4}$ did not result in clean conversion to the corresponding radical cations, as might be expected after consideration of their cyclic voltammograms. Rather, solids that were insoluble in common organic solvents were reproducibly formed. These solids did not give rise to observable EPR spectra, but their mass spectra contained peaks corresponding to $[2 \mathrm{M}-2 \mathrm{H}]^{+}$fragments supporting our earlier claim that the irreversible electrochemical oxidation waves observed during our cyclic voltammetry experiments are likely the result of radical-radical coupling reactions. We hypothesize that structures such as 12 and $\mathbf{1 3}$ form via sequential radical coupling and loss of two protons (Scheme 3).

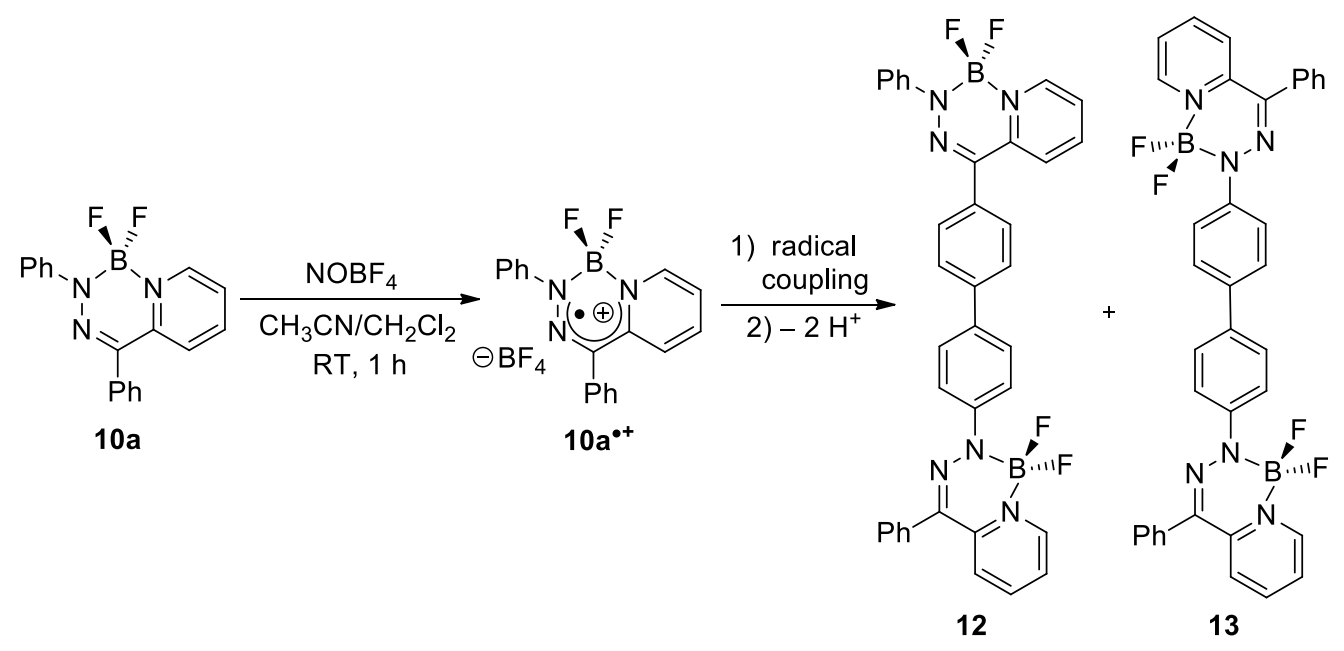

Scheme 3. Potential dimer formation via chemical oxidation of BODIHY 10a.

\section{CONCLUSIONS}

By systematically studying the synthesis and properties of double-rotor BODIHY dyes, we have arrived at the following conclusions. 1) The absorption and photoluminescence properties of these dyes are tunable via variation of the $N$-aryl groups. In general, electron-donating and $\pi$-conjugated substituents lead to red-shifted absorption and photoluminescence bands compared to the phenylsubstituted analogue, while electron-withdrawing substituents lead to blue-shifted maxima. 2) The double-rotor molecular architecture of BODIHYs leads to poor photoluminescence efficiency in solution due to non-radiative decay pathways associated with the vibration and/or rotation of the $N$ aryl and $C$-aryl groups. However, thin films of the title BODIHYs are photoluminescent with lifetimes on the order of $1.5 \mathrm{~ns}$. Aggregation studies confirmed that restricted intramolecular motion 
is the likely origin of the differing behavior in solution and the solid state. 3) The introduction of a $C$-phenyl groups at the BODIHY framework leads to accessible boratahydrazyl radical cations via electrochemical or chemical oxidation, presumably due to enhanced resonance delocalization. The stability of the resulting radical cations is largely dependent on the presence/absence of parasubstituents at the $N$-aryl rings. In the absence of these substituents it appears that radical dimerization pathways lead to decomposition. When a $p$-anisole group is introduced, radical cations with sufficient stability to allow for their characterization are produced. Collectively, these findings open up new opportunities for materials-based applications of BODIHY dyes and provide guiding principles for future examples of BODIHYs and related $\mathrm{BF}_{2}$ complexes of chelating $N$-donor ligands. Our future work will aim to exploit these unique properties in multifunctional polymer architectures.

\section{ACKNOWLEDGEMENTS}

This research was supported by the Natural Sciences and Engineering Research Council (NSERC) of Canada (V.N.S.: DG RGPIN-2015-04814, F.L.L.: DG, RGPIN-2015-04298, J.B.G.: DG, RGPIN-2018-04240), the Ontario Ministry of Research and Innovation (J.B.G.: ERA, ER-14-10147) and the Canadian Foundation for Innovation (J.B.G.: JELF, 33977). The authors thank Mr. Ryan R. Maar (X-ray Crystallography), Dr. Paul Bazylewski and Dr. Giovanni Fanchini (EPR spectroscopy), as well as Dr. Xiang Wang and Dr. Suning Wang (quantum yield determination) for performing the measurements and providing access to instrumentation.

\section{METHODS}

\section{General Experimental Details}

Reactions were carried out under an $\mathrm{N}_{2}$ atmosphere using standard Schlenk techniques unless otherwise stated. Solvents were obtained from Caledon Laboratories, dried using an Innovative Technologies Inc. solvent purification system, collected under vacuum and stored under an $\mathrm{N}_{2}$ atmosphere over 4 A molecular sieves. Reagents were purchased from Sigma-Aldrich, Alfa Aesar, or Oakwood Chemicals and used as received. Hydrazones 8a, 8b, and $8 \mathbf{c}$ have been reported previously with relatively few details of their synthesis and characterization. ${ }^{[22]}$ Hydrazone $\mathbf{9 b}$ has been synthesized previously by an alternative procedure with discrepancies between our data and those reported. ${ }^{[23]}$ For completion, full synthetic and characterization details are included below. NMR spectra were recorded on a Bruker AvanceIII HD $400 \mathrm{MHz}$ Spectrometer ( ${ }^{1} \mathrm{H}: 399.8 \mathrm{MHz}$, 
$\left.{ }^{13} \mathrm{C}\left\{{ }^{1} \mathrm{H}\right\}: 100.6 \mathrm{MHz},{ }^{11} \mathrm{~B}: 128.3 \mathrm{MHz},{ }^{19} \mathrm{~F}: 376.1 \mathrm{MHz}\right) .{ }^{1} \mathrm{H}$ NMR spectra were referenced to residual $\mathrm{CHCl}_{3}(7.26 \mathrm{ppm})$ or DMSO- $d_{5}(2.50 \mathrm{ppm})$ and ${ }^{13} \mathrm{C}\left\{{ }^{1} \mathrm{H}\right\}$ NMR spectra were referenced to $\mathrm{CDCl}_{3}(77.2 \mathrm{ppm})$ or DMSO- $d_{6}(39.5 \mathrm{ppm}) .{ }^{11} \mathrm{~B} \mathrm{NMR}$ spectra were reported relative to $\mathrm{BF}_{3} \cdot \mathrm{OEt}_{3}(0$ $\mathrm{ppm})$ and ${ }^{19} \mathrm{~F}$ NMR spectra were referenced to $\mathrm{CFCl}_{3}(0 \mathrm{ppm})$. Mass spectrometry data were recorded in positive-ion mode using a Thermo Scientific DFS (Double Focusing Sector) mass spectrometer using electron impact ionization. UV-vis absorption spectra were recorded using a Cary 5000 spectrophotometer between 200 and $2000 \mathrm{~nm}$. Molar extinction coefficients were determined from the slope of a plot of absorbance versus concentration containing four separate sample concentrations. FT-IR spectra were recorded using an attenuated total reflectance (ATR) attachment using a Perkin Elmer Spectrum Two FT-IR spectrometer. PL spectra were obtained using a Photon Technology International QM-4 SE spectrofluorometer. Excitation wavelengths were chosen based on $\lambda_{\max }$ from the respective UV-vis absorption spectrum in the same solvent. Solution-state quantum yields were estimated relative to $\left[\mathrm{Ru}(\text { bipy })_{3}\right]\left[\mathrm{PF}_{6}\right]_{2}$ under identical conditions by established methods and corrected for wavelength-dependent detector sensitivity (Figure S40). ${ }^{[24]}$ Solid-state absolute quantum yields were measured using a Hamamatsu C11347 Quantaurus Absolute PL Quantum Yield Spectrometer.

\section{X-Ray Crystallography Methods}

Single crystals suitable for X-ray diffraction studies were grown by vapor diffusion of hexanes into a saturated $\mathrm{CH}_{2} \mathrm{Cl}_{2}$ solution of $\mathbf{1 0 a}$ or by the slow evaporation of a saturated $\mathrm{CH}_{2} \mathrm{Cl}_{2}$ solution of $\mathbf{1 0 b}$ or 10d. The sample crystals were mounted on a MiTeGen polyimide micromounts with a small amount of Paratone $N$ oil. X-ray diffraction measurements were made on a Nonius KappaCCD Axis Apex2 (10a and 10b) or Bruker Kappa Axis Apex2 (10d) diffractometer at a temperature of $110 \mathrm{~K}$. The data collection strategy included a number of $\omega$ and $\varphi$ scans. The frame integration was performed using SAINT. ${ }^{[25]}$ The resulting raw data were scaled and absorption-corrected using a multiscan averaging of symmetry equivalent data using SADABS. ${ }^{[26]}$ The structures were solved using a dual space methodology using the SHELXT program. ${ }^{[27]}$ All non-hydrogen atoms were obtained from the initial solution. The $\mathrm{CF}_{3}$ group in 10d was disordered. The normalized occupancy for the dominant conformer is $82.7(4) \%$. The hydrogen atoms were introduced at idealized positions and allowed to ride on the parent atom (10a and 10b) or refined isotropically (10d). The structural model was fit to the data using full matrix least-squares based on $F^{2}$. The calculated structure factors included corrections for anomalous dispersion from the usual tabulation. The structure was 
refined using the SHELXL program from the SHELX suite of crystallographic software. ${ }^{[28]}$ Graphic plots were produced using Mercury version 3.8. See Table S1 and CCDC 1889791-1889793 for additional crystallographic data.

\section{Computational Methods}

Calculations were performed using the Gaussian suite of programs. ${ }^{[29]}$ Molecular geometries were optimized at the PBE1PBE/6-311+G* level of theory using the polarizable continuum model of implicit solvation by $\mathrm{CH}_{2} \mathrm{Cl}_{2}$. All optimized structures were confirmed to be true minima by performing vibrational analysis. The UV-vis absorption spectra of 10a, 10c, and 10d were simulated using the output of adiabatic linear-response TDDFT calculations for the lowest 40 singlet-to-singlet electronic transitions; the peak width was set to $50 \mathrm{~nm}$.

\section{Thin-Film Preparation}

Thin-films of BODIHY complexes 10a-e were prepared for absorption, PL, and FLIM studies by filtering (PTFE membrane, $0.22 \mu \mathrm{m}$ ) approximately $300 \mu \mathrm{L}$ of a $20 \mathrm{mg} \mathrm{mL}^{-1}$ solution of each compound in $\mathrm{CH}_{2} \mathrm{Cl}_{2}$ directly onto a quartz or glass slides. The samples were left at rest for $1 \mathrm{~min}$ and then accelerated at a rate of $100 \mathrm{rpm} \mathrm{s}^{-1}$ to $500 \mathrm{rpm}$ for $10 \mathrm{~s}$ followed by acceleration at a rate of $500 \mathrm{rpm} \mathrm{s}^{-1}$ to $2000 \mathrm{rpm}$ for $30 \mathrm{~s}$ before air drying. Thin-films of PMMA doped with BODIHYs 10a-e were prepared by filtering (PTFE membrane, $0.22 \mu \mathrm{m}$ ) approximately $300 \mu \mathrm{L}$ of a $20 \mathrm{mg}$ $\mathrm{mL}^{-1}$ solution of 99:1 (by mass) PMMA:BODIHY in $\mathrm{CH}_{2} \mathrm{Cl}_{2}$ directly onto a glass microscope coverslip. The samples were left at rest for $1 \mathrm{~min}$ and then accelerated at a rate of $300 \mathrm{rpm} \mathrm{s}^{-1}$ to $1000 \mathrm{rpm}$ for $1 \mathrm{~min}$. These parameters yield thin films with thickness in the range of approximately $0.5 \mu \mathrm{m}$.

\section{Fluorescence-Lifetime Imaging Microscopy}

FLIM experiments were carried out on a Leica confocal fluorescence microscope (TCS SP2, Wetzlar, Germany) equipped with a time-correlated single-photon counting (TCSPC) module (PicoHarp 300, PicoQuant). Samples were excited at $800 \mathrm{~nm}$ with a pulsed Ti:sapphire femtosecond laser system (Mira 900, Coherent, $\sim 150$ fs pulse duration at the sample) with a repetition rate of $76 \mathrm{MHz}$. Two-photon induced fluorescence signal was collected through an oil immersion objective $(\times 63,1.32 \mathrm{NA})$, the scanning area for the image was set to $512 \times 512$ pixels and the emission was collected below $750 \mathrm{~nm}$. 


\section{Aggregation Studies}

Solutions containing various ratios of THF and deionized water $(9.5 \mathrm{~mL})$ were combined with a 4 $\mathrm{mM}$ stock solution of BODIHY in THF $(0.5 \mathrm{~mL})$ to yield $200 \mu \mathrm{M}$ solutions of BODIHY with volume fractions $\left(f_{\mathrm{w}}\right)$ of $0,10,20,30,40,50,60,70,75,80,82.5,85,87.5,90,92.5$ and $95 \%$. The resulting solutions were mixed by inversion in a volumetric flask for $30 \mathrm{~s}$, left to stand for an additional $30 \mathrm{~s}$, and then analyzed immediately. This entire process was repeated in triplicate for each compound and concentration reported.

\section{Electrochemical Methods}

Cyclic voltammetry experiments were performed with a Bioanalytical Systems Inc. (BASi) Epsilon potentiostat and analyzed using BASi Epsilon software. Electrochemical cells consisted of a threeelectrode setup including a glassy carbon working electrode, a platinum wire counter electrode and a silver wire pseudo reference electrode. Experiments were run at scan rates of $50-1000 \mathrm{mV} \mathrm{s}^{-1}$ in degassed solutions of $\mathrm{CH}_{3} \mathrm{CN}$ containing the analyte $(\sim 1 \mathrm{mM})$ and supporting electrolyte $(0.1 \mathrm{M}$ $\left.\left[n \mathrm{Bu}_{4} \mathrm{~N}\right]\left[\mathrm{PF}_{6}\right]\right)$. Cyclic voltammograms were internally referenced against the ferrocene/ferrocenium redox couple $(\sim 1 \mathrm{mM}$ ferrocene as an internal standard) and corrected for internal cell resistance using the BASi Epsilon software.

\section{Electron Paramagnetic Resonance (EPR) Spectroscopy}

The EPR spectrum of $\mathbf{1 0 c}^{\bullet+}$ was obtained for a $\sim 2 \mathrm{mg} \mathrm{mL}^{-1}$ solution in $\mathrm{CH}_{2} \mathrm{Cl}_{2}$ in a $0.4 \mathrm{~mm}$ quartz capillary tube using a JEOL JES-FA200 EPR spectrometer. The measurement was made at $298 \mathrm{~K}$ and the $g$-factor determined for $10 \mathbf{c}^{\bullet+}$ was referenced relative to a built-in $\mathrm{Mn}^{2+}$ marker within the resonant cavity of the instrument. The products isolated during the attempted oxidation of BODIHYs 10a and 10e were analyzed as powders using the same instrument.

\section{Representative procedure for the preparation of hydrazones 8a-8e. Hydrazone 8a}

In air, phenylhydrazine $(2.00 \mathrm{~g}, 1.82 \mathrm{~mL}, 18.5 \mathrm{mmol})$ was added to a solution of 2-benzoylpyridine (3.40 g, $18.5 \mathrm{mmol})$ in anhydrous EtOH $(30 \mathrm{~mL})$. The pale-yellow solution was refluxed with stirring for $6 \mathrm{~h}$. The reaction mixture was then concentrated in vacuo, and the resulting residue was recrystallized from hot anhydrous EtOH to afford hydrazone 8a as a pale-yellow crystalline solid that was collected by vacuum filtration. Yield $=4.42 \mathrm{~g}, 88 \%$. M.p. $=176-178{ }^{\circ} \mathrm{C} .{ }^{1} \mathrm{H}$ NMR 
(399.8 MHz, DMSO- $\left.d_{6}\right): \delta 9.11(\mathrm{~s}, 1 \mathrm{H}, \mathrm{N} H), 8.37\left(\mathrm{~d},{ }^{3} J_{\mathrm{HH}}=4 \mathrm{~Hz}, 1 \mathrm{H}\right.$, aryl $\left.\mathrm{CH}\right), 8.16\left(\mathrm{~d},{ }^{3} J_{\mathrm{HH}}=\right.$ $8 \mathrm{~Hz}, 1 \mathrm{H}$, aryl $\mathrm{CH}), 7.82\left(\mathrm{t},{ }^{3} \mathrm{JHH}_{\mathrm{HH}}=8 \mathrm{~Hz}, 1 \mathrm{H}\right.$, aryl $\left.\mathrm{CH}\right), 7.55-7.45(\mathrm{~m}, 3 \mathrm{H}$, aryl $\mathrm{CH}), 7.31-7.20(\mathrm{~m}$, $7 \mathrm{H}$, aryl $\mathrm{CH}), 6.81\left(\mathrm{t},{ }^{3} J_{\mathrm{HH}}=7 \mathrm{~Hz}, 1 \mathrm{H}\right.$, aryl $\left.\mathrm{CH}\right) .{ }^{13} \mathrm{C}\left\{{ }^{1} \mathrm{H}\right\}$ NMR $\left(100.6 \mathrm{MHz}\right.$, DMSO-d $\left.d_{6}\right): \delta 156.6$, 148.3, 144.9, 143.1, 136.2, 132.7, 129.4, 128.9, 128.8, 128.5, 122.2, 120.1, 119.8, 113.3. FT-IR (ATR): $3057(\mathrm{w}), 2361(\mathrm{w}), 2334(\mathrm{w}), 1602$ (s), $849(\mathrm{~m}), 692(\mathrm{~s}) \mathrm{cm}^{-1}$. UV-vis $\left(\mathrm{CH}_{2} \mathrm{Cl}_{2}\right): \lambda_{\max }=$ $353 \mathrm{~nm}\left(\varepsilon=23700 \mathrm{M}^{-1} \mathrm{~cm}^{-1}\right), 295 \mathrm{~nm}\left(\varepsilon=11800 \mathrm{M}^{-1} \mathrm{~cm}^{-1}\right), 241 \mathrm{~nm}\left(\varepsilon=18300 \mathrm{M}^{-1} \mathrm{~cm}^{-1}\right)$. Mass Spec. (EI, +ve mode): exact mass calculated for $\left[\mathrm{C}_{18} \mathrm{H}_{14} \mathrm{~N}_{3}\right]^{+},[\mathrm{M}-\mathrm{H}]^{+}: 272.1188$; exact mass found: 272.1186; difference: -0.7 ppm.

\section{Hydrazone 8b}

From $p$-tolylhydrazine $\cdot \mathrm{HCl}(2.93 \mathrm{~g}, 18.5 \mathrm{mmol})$ and 2-benzoylpyridine $(3.40 \mathrm{~g}, 18.5 \mathrm{mmol})$. Yield $=4.20 \mathrm{~g}, 79 \%$ (orange solid). M.p. $=182-183{ }^{\circ} \mathrm{C} .{ }^{1} \mathrm{H}$ NMR $\left(399.8 \mathrm{MHz}, \mathrm{DMSO}-d_{6}\right): \delta 10.07$ (s, $1 \mathrm{H}, \mathrm{NH}), 8.80(\mathrm{~m}, 1 \mathrm{H}$, aryl $\mathrm{CH}), 8.33\left(\mathrm{t},{ }^{3} J_{\mathrm{HH}}=8 \mathrm{~Hz}, 1 \mathrm{H}\right.$, aryl $\left.\mathrm{CH}\right), 7.77\left(\mathrm{t},{ }^{3} J_{\mathrm{HH}}=7 \mathrm{~Hz}, 1 \mathrm{H}\right.$, aryl $\mathrm{CH}), 7.68-7.57(\mathrm{~m}, 5 \mathrm{H}$, aryl $\mathrm{CH}), 7.44\left(\mathrm{~d},{ }^{3} J_{\mathrm{HH}}=7 \mathrm{~Hz}, 2 \mathrm{H}\right.$, aryl $\left.\mathrm{CH}\right), 7.34\left(\mathrm{~d},{ }^{3} J_{\mathrm{HH}}=8 \mathrm{~Hz}, 1 \mathrm{H}\right.$, aryl $\mathrm{CH}), 7.07\left(\mathrm{~d},{ }^{3} J_{\mathrm{HH}}=8 \mathrm{~Hz}, 2 \mathrm{H}\right.$, aryl $\left.\mathrm{CH}\right), 2.25\left(\mathrm{~s}, 3 \mathrm{H}, \mathrm{CH}_{3}\right) .{ }^{13} \mathrm{C}\left\{{ }^{1} \mathrm{H}\right\}$ NMR $\left(100.6 \mathrm{MHz}\right.$, DMSO- $\left.d_{6}\right)$ : $\delta$ 149.0, 145.4, 142.8, 141.2, 133.1, 130.7, 130.1, 130.0, 129.8, 129.5, 129.3, 123.7, 123.6, 115.1, 20.4. FT-IR (ATR): 3087 (w), 2361 (w), 1611 (w), 1250 (s), 818 (m) cm $\mathrm{cm}^{-1}$. UV-vis $\left(\mathrm{CH}_{2} \mathrm{Cl}_{2}\right): \lambda_{\max }=$ $439 \mathrm{~nm}\left(\varepsilon=19800 \mathrm{M}^{-1} \mathrm{~cm}^{-1}\right), 331 \mathrm{~nm}\left(\varepsilon=8800 \mathrm{M}^{-1} \mathrm{~cm}^{-1}\right), 242 \mathrm{~nm}\left(\varepsilon=13200 \mathrm{M}^{-1} \mathrm{~cm}^{-1}\right)$. Mass Spec. (EI, +ve mode): exact mass calculated for $\left[\mathrm{C}_{19} \mathrm{H}_{16} \mathrm{~N}_{3}\right]^{+},[\mathrm{M}-\mathrm{H}]^{+}: 286.1344$; exact mass found: 286.1350 ; difference: +2.1 ppm.

\section{Hydrazone 8c}

From $p$-(methoxy)phenylhydrazine $\bullet \mathrm{HCl}(3.23 \mathrm{~g}, 18.5 \mathrm{mmol})$ and 2-benzoylpyridine $(3.40 \mathrm{~g}$, 18.5 mmol. Yield $=4.82 \mathrm{~g}, 86 \%$ (red solid). M.p. $=188-191{ }^{\circ} \mathrm{C} .{ }^{1} \mathrm{H}$ NMR $\left(399.8 \mathrm{MHz}\right.$, DMSO- $\left.d_{6}\right)$ : $\delta 10.15(\mathrm{~s}, 1 \mathrm{H}, \mathrm{NH}), 8.82\left(\mathrm{~d},{ }^{3} J_{\mathrm{HH}}=6 \mathrm{~Hz}, 1 \mathrm{H}\right.$, aryl $\left.\mathrm{CH}\right), 8.34\left(\mathrm{t},{ }^{3} \mathrm{~J}_{\mathrm{HH}}=8 \mathrm{~Hz}, 1 \mathrm{H}, \operatorname{aryl} \mathrm{CH}\right), 7.77(\mathrm{t}$, ${ }^{3} J_{\mathrm{HH}}=8 \mathrm{~Hz}, 1 \mathrm{H}$, aryl $\left.\mathrm{CH}\right), 7.70-7.60(\mathrm{~m}, 5 \mathrm{H}, \operatorname{aryl} \mathrm{CH}), 7.46\left(\mathrm{~d}, 2 \mathrm{H},{ }^{3} J_{\mathrm{HH}}=6 \mathrm{~Hz}\right.$, aryl $\left.\mathrm{CH}\right), 7.25(\mathrm{~d}$, $1 \mathrm{H},{ }^{3} \mathrm{~J}_{\mathrm{HH}}=8 \mathrm{~Hz}$, aryl $\left.\mathrm{CH}\right), 6.86\left(\mathrm{~d}, 2 \mathrm{H},{ }^{3} J_{\mathrm{HH}}=9 \mathrm{~Hz}\right.$, aryl $\left.\mathrm{CH}\right), 3.72\left(\mathrm{~s}, 3 \mathrm{H}, \mathrm{OCH}_{3}\right) .{ }^{13} \mathrm{C}\left\{{ }^{1} \mathrm{H}\right\} \mathrm{NMR}$ $\left(100.6 \mathrm{MHz}, \mathrm{DMSO}-d_{6}\right): \delta 154.9,148.9,145.7,142.4,137.1,132.1,130.2,130.1,129.9,129.5$, 123.7, 123.4, 116.5, 114.1, 55.3. FT-IR (ATR): 2979 (m), 2940 (m), 2598 (s), 2495 (s), 1509 (m),1034 (s), $851(\mathrm{~m}), 803(\mathrm{~m}) \mathrm{cm}^{-1}$. UV-vis $\left(\mathrm{CH}_{2} \mathrm{Cl}_{2}\right): \lambda_{\max }=472 \mathrm{~nm}\left(\varepsilon=2700 \mathrm{M}^{-1} \mathrm{~cm}^{-1}\right)$, $364 \mathrm{~nm}\left(\varepsilon=15500 \mathrm{M}^{-1} \mathrm{~cm}^{-1}\right), 274 \mathrm{~nm}\left(\varepsilon=56300 \mathrm{M}^{-1} \mathrm{~cm}^{-1}\right)$. Mass Spec. (EI, +ve mode): exact 
mass calculated for $\left[\mathrm{C}_{19} \mathrm{H}_{17} \mathrm{~N}_{3} \mathrm{O}\right]^{+},[\mathrm{M}]^{+}$: 303.1372; exact mass found: 303.1383; difference: $+3.6 \mathrm{ppm}$.

\section{Hydrazone 8d}

From $p$-(trifluoromethyl)phenylhydrazine $\cdot \mathrm{HCl}(3.93 \mathrm{~g}, 18.5 \mathrm{mmol})$ and 2-benzoylpyridine $(3.40 \mathrm{~g}$, $18.5 \mathrm{mmol}$ ). Yield $=3.66 \mathrm{~g}, 58 \%$ (yellow-orange solid). M.p. $=201-202{ }^{\circ} \mathrm{C} .{ }^{1} \mathrm{H} \mathrm{NMR}(399.8 \mathrm{MHz}$, DMSO-d $\left.d_{6}\right): \delta 9.63(\mathrm{~s}, 1 \mathrm{H}, \mathrm{N} H), 8.41-8.39(\mathrm{~m}, 1 \mathrm{H}$, aryl $\mathrm{CH}), 8.17\left(\mathrm{~d},{ }^{3} J_{\mathrm{HH}}=8 \mathrm{~Hz}, 1 \mathrm{H}\right.$, aryl $\left.\mathrm{CH}\right)$, 7.87-7.83 (m, 1H, aryl CH), 7.58-7.52 (m, 4H, aryl $\mathrm{CH}), 7.51-7.49(\mathrm{~m}, 1 \mathrm{H}$, aryl $\mathrm{CH}), 7.47-7.44$ $(\mathrm{m}, 2 \mathrm{H}$, aryl $\mathrm{CH}), 7.33-7.28(\mathrm{~m}, 3 \mathrm{H}$, aryl $\mathrm{CH}) .{ }^{13} \mathrm{C}\left\{{ }^{1} \mathrm{H}\right\}$ NMR (100.6 MHz, DMSO- $\left.d_{6}\right): \delta$ 156.7, $148.9,148.7,145.9,136.9,133.0,129.9,129.3,129.2,126.6$ (q, ${ }^{1} J_{\mathrm{CF}}=4 \mathrm{~Hz}, C \mathrm{~F}_{3}$ ), 123.2, 121.0, 120.1, 119.8, 113.7. ${ }^{19} \mathrm{~F}$ NMR (376.1 MHz, DMSO- $\left.d_{6}\right): \delta-59.5$ (s, CF $F_{3}$ ). FT-IR (ATR): $3170(\mathrm{w})$, $2985(\mathrm{w}), 1741(\mathrm{w}), 1614(\mathrm{~m}), 1263(\mathrm{~m}), 837(\mathrm{~m}) \mathrm{cm}^{-1}$. UV-vis $\left(\mathrm{CH}_{2} \mathrm{Cl}_{2}\right): \lambda_{\max }=341 \mathrm{~nm}(\varepsilon=$

$\left.28300 \mathrm{M}^{-1} \mathrm{~cm}^{-1}\right), 305 \mathrm{~nm}\left(\varepsilon=11400 \mathrm{M}^{-1} \mathrm{~cm}^{-1}\right), 247 \mathrm{~nm}\left(\varepsilon=13900 \mathrm{M}^{-1} \mathrm{~cm}^{-1}\right)$. Mass Spec. (EI, +ve mode): exact mass calculated for $\left[\mathrm{C}_{19} \mathrm{H}_{13} \mathrm{~F}_{3} \mathrm{~N}_{3}\right]^{+},[\mathrm{M}-\mathrm{H}]^{+}: 340.1062$; exact mass found: 340.1062 ; difference: 0 ppm.

\section{Hydrazone 8e}

From 2-napthylhydrazine $\cdot \mathrm{HCl}(3.60 \mathrm{~g}, 18.5 \mathrm{mmol})$ and 2-benzoylpyridine $(3.40 \mathrm{~g}, 18.5 \mathrm{mmol})$. Yield $=4.31 \mathrm{~g}, 72 \%$ (orange solid). M.p. $=181-183{ }^{\circ} \mathrm{C} .{ }^{1} \mathrm{H}$ NMR $\left(399.8 \mathrm{MHz}\right.$, DMSO- $\left.d_{6}\right): \delta$ $10.26(\mathrm{~s}, 1 \mathrm{H}$, aryl $\mathrm{CH}), 8.80\left(\mathrm{~d},{ }^{3} J_{H H}=5 \mathrm{~Hz}, 1 \mathrm{H}\right.$, aryl $\left.\mathrm{CH}\right), 8.32\left(\mathrm{t},{ }^{3} J_{H H}=8 \mathrm{~Hz}, 1 \mathrm{H}\right.$, aryl CH$), 8.07$ $\left(\mathrm{s}, 1 \mathrm{H}\right.$, aryl CH), $7.89\left(\mathrm{~d},{ }^{3} J_{H H}=9 \mathrm{~Hz}, 1 \mathrm{H}\right.$, aryl CH), 7.85-7.74 (m, 4H, aryl CH), 7.70-7.62 (m, 3H, aryl $\mathrm{CH}), 7.54-7.40(\mathrm{~m}, 4 \mathrm{H}$, aryl $\mathrm{CH}), 7.32\left(\mathrm{t},{ }^{3} J_{H H}=8 \mathrm{~Hz}, 1 \mathrm{H}\right.$, aryl CH). ${ }^{13} \mathrm{C}\left\{{ }^{1} \mathrm{H}\right\} \mathrm{NMR}(100.6$ MHz, DMSO-d $\left.d_{6}\right): \delta 149.6,144.9,143.4,141.4,135.3,133.9,130.1,129.9,129.8,129.7,129.3$, 128.6, 127.6, 126.9, 126.4, 123.9, 123.8, 123.7, 116.7, 109.8. FT-IR (ATR): 3290 (m), 2290 (m), $2897(\mathrm{w}), 1603(\mathrm{~m}), 1546(\mathrm{~s}), 1513(\mathrm{~s}), 1448(\mathrm{~s}) \mathrm{cm}^{-1}$. UV-vis $\left(\mathrm{CH}_{2} \mathrm{Cl}_{2}\right): \lambda_{\max }=443 \mathrm{~nm}(\varepsilon=$ $\left.18900 \mathrm{M}^{-1} \mathrm{~cm}^{-1}\right), 248 \mathrm{~nm}\left(\varepsilon=13600 \mathrm{M}^{-1} \mathrm{~cm}^{-1}\right), 236 \mathrm{~nm}\left(\varepsilon=34500 \mathrm{M}^{-1} \mathrm{~cm}^{-1}\right.$ ). Mass Spec. (EI, +ve mode): exact mass calculated for $\left[\mathrm{C}_{22} \mathrm{H}_{16} \mathrm{~N}_{3}\right]^{+},[\mathrm{M}-\mathrm{H}]^{+}$: 322.1344; exact mass found: 322.1347; difference: +0.9 ppm. 


\section{Hydrazone 9b}

According to a modified literature procedure ${ }^{[13 \mathrm{~d}]} p$-toluidine $(1.07 \mathrm{~g}, 9.99 \mathrm{mmol})$ was dissolved in a mixture of concentrated $\mathrm{HCl}(6 \mathrm{~mL})$ and and cold deionized water $(12 \mathrm{~mL})$ and stirred at $0{ }^{\circ} \mathrm{C}$ for $15 \mathrm{~min}$. Sodium nitrite $(0.76 \mathrm{~g}, 11.0 \mathrm{mmol})$ was dissolved in $3 \mathrm{~mL}$ of cold deionized water and added dropwise to the $p$-toluidine solution over a 30 min period. The pale-yellow solution was stirred at $0{ }^{\circ} \mathrm{C}$ for $1 \mathrm{~h}$. This solution was added dropwise to a suspension of 2-pyridylacetonitrile $(1.18 \mathrm{~g}, 9.99 \mathrm{mmol})$ and sodium acetate $(4.10 \mathrm{~g}, 50.0 \mathrm{mmol})$ in cold EtOH $(36 \mathrm{~mL})$ and cold deionized water $(9 \mathrm{~mL})$ over a 30 min period. The resulting mixture was stirred at room temperature for $16 \mathrm{~h}$ before cold deionized water $(100 \mathrm{~mL})$ was added to induce precipitation. The resulting pale-yellow precipitate was collected by vacuum filtration. The crude solid was dissolved in $\mathrm{CH}_{2} \mathrm{Cl}_{2}$ and the resulting solution was washed with saturated sodium bicarbonate solution thrice, brine thrice, and finally dried over $\mathrm{MgSO}_{4}$. After solvent removal, further purification by column chromatography (1:6 ethyl acetate/hexane, silica gel) to afford $\mathbf{9 b}$ as a yellow powder. Yield $=$ $1.39 \mathrm{~g}, 58 \%$. Melting point $=170-173{ }^{\circ} \mathrm{C} .{ }^{1} \mathrm{H}$ NMR $\left(399.8 \mathrm{MHz}, \mathrm{CDCl}_{3}\right): \delta 14.97(\mathrm{~s}, 1 \mathrm{H}, \mathrm{NH})$, $8.65-8.60(\mathrm{~m}, 1 \mathrm{H}$, aryl CH$), 7.88\left(\mathrm{ddd},{ }^{3} J_{\mathrm{HH}}=8 \mathrm{~Hz},{ }^{3} J_{\mathrm{HH}}=8 \mathrm{~Hz},{ }^{4} J_{\mathrm{HH}}=\mathrm{Hz}, 1 \mathrm{H}\right.$, aryl CH$), 7.76$ $\left(\mathrm{dt},{ }^{3} \mathrm{~J}_{\mathrm{HH}}=8 \mathrm{~Hz},{ }^{4} \mathrm{~J}_{\mathrm{HH}}=1 \mathrm{~Hz}, 1 \mathrm{H}\right.$, aryl $\left.\mathrm{CH}\right), 7.34-7.29(\mathrm{~m}, 1 \mathrm{H}$, aryl $\mathrm{CH}), 7.29-7.24(\mathrm{~m}, 2 \mathrm{H}$, aryl $\mathrm{CH}), 7.19-7.14(\mathrm{~m}, 2 \mathrm{H}$, aryl $\mathrm{CH}), 2.35\left(\mathrm{~s}, 3 \mathrm{H}, \mathrm{CH}_{3}\right) .{ }^{13} \mathrm{C}\left\{{ }^{1} \mathrm{H}\right\}$ NMR $\left(100.6 \mathrm{MHz}\right.$, DMSO- $\left.d_{6}\right): \delta$ 152.5, 147.2, 140.1, 137.6, 133.7, 130.0, 122.7, 121.8, 117.8, 115.0, 110.6, 21.0. FT-IR (ATR): 3077 (w), 2920 (w), 2215 (M), 1589 (s), 1524 (s), 779 (s) cm ${ }^{-1}$. UV-vis $\left(\mathrm{CH}_{2} \mathrm{Cl}_{2}\right)$ : $\lambda_{\max }=382 \mathrm{~nm}(\varepsilon$ $\left.=25700 \mathrm{M}^{-1} \mathrm{~cm}^{-1}\right), 275 \mathrm{~nm}\left(\varepsilon=12300 \mathrm{M}^{-1} \mathrm{~cm}^{-1}\right), 252 \mathrm{~nm}\left(\varepsilon=13200 \mathrm{M}^{-1} \mathrm{~cm}^{-1}\right)$. Mass Spec. (EI, +ve mode): exact mass calculated for $\left[\mathrm{C}_{14} \mathrm{H}_{12} \mathrm{~N}_{4}\right]^{+},[\mathrm{M}]^{+}$: 236.1062; exact mass found: 236.1068; difference: $+2.5 \mathrm{ppm}$.

\section{Representative procedure for the preparation of BODIHYs 10a-10e. BODIHY 10a}

Dry $\mathrm{NEt}_{3}(1.12 \mathrm{~g}, 1.54 \mathrm{~mL}, 11.1 \mathrm{mmol})$ was added to a stirred solution of $8 \mathbf{a}(1.01 \mathrm{~g}, 3.70 \mathrm{mmol})$ in dry toluene $(80 \mathrm{~mL})$. After $10 \mathrm{~min}, \mathrm{BF}_{3} \cdot \mathrm{OEt}_{2}(2.62 \mathrm{~g}, 2.28 \mathrm{~mL}, 18.5 \mathrm{mmol})$ was added dropwise and the solution rapidly changed colour from pale-yellow to deep red/purple, then to deep orange over a 15 min period. The solution was then stirred at $80^{\circ} \mathrm{C}$ for $16 \mathrm{~h}$. After cooling to room temperature, deionized water $(20 \mathrm{~mL})$ was added to quench reactive boron-containing species. The deep orange solution was then washed with deionized water $(3 \times 20 \mathrm{~mL})$, dried over $\mathrm{MgSO}_{4}$, gravity filtered and concentrated in vacuo. The deep yellow/orange residue was triturated with ice cold $\mathrm{MeOH}$ to afford 10a as a yellow solid after vacuum filtration. Yield $=1.10 \mathrm{~g}, 92 \%$. M.p. $=$ 
$182-185{ }^{\circ} \mathrm{C} .{ }^{1} \mathrm{H}$ NMR $\left(399.8 \mathrm{MHz}, \mathrm{CDCl}_{3}\right): \delta 8.77\left(\mathrm{~d},{ }^{3} J_{\mathrm{HH}}=6 \mathrm{~Hz}, 1 \mathrm{H}\right.$, aryl $\left.\mathrm{CH}\right), 8.02\left(\mathrm{ddd},{ }^{3} J_{\mathrm{HH}}=\right.$ $9 \mathrm{~Hz},{ }^{3} J_{\mathrm{HH}}=7 \mathrm{~Hz},{ }^{4} J_{\mathrm{HH}}=2 \mathrm{~Hz}, 1 \mathrm{H}$, aryl $\left.\mathrm{CH}\right), 7.72\left(\mathrm{t},{ }^{3} J_{\mathrm{HH}}=8 \mathrm{~Hz}, 3 \mathrm{H}\right.$, aryl $\left.\mathrm{CH}\right), 7.65-7.63(\mathrm{~m}, 2 \mathrm{H}$, aryl $\mathrm{CH}), 7.60-7.55(\mathrm{~m}, 1 \mathrm{H}$, aryl $\mathrm{CH}), 7.52-7.47(\mathrm{~m}, 2 \mathrm{H}$, aryl $\mathrm{CH}), 7.46-7.41(\mathrm{~m}, 1 \mathrm{H}$, aryl $\mathrm{CH})$, 7.39-7.34 (m, 2H, aryl $\mathrm{CH}), 7.13-7.09(\mathrm{~m}, 1 \mathrm{H}$, aryl $\mathrm{CH}) .{ }^{11} \mathrm{~B} \mathrm{NMR}\left(128.3 \mathrm{MHz}, \mathrm{CDCl}_{3}\right): \delta 0.7(\mathrm{t}$, $\left.{ }^{1} J_{\mathrm{BF}}=32 \mathrm{~Hz}\right) .{ }^{13} \mathrm{C}\left\{{ }^{1} \mathrm{H}\right\} \mathrm{NMR}\left(100.5 \mathrm{MHz}, \mathrm{CDCl}_{3}\right): \delta 146.2,141.5,141.2,139.9,136.0,133.7$, 129.4, 128.9, 128.8, 128.5, 124.0, 122.9, 122.7, 119.9. $\left.{ }^{19} \mathrm{~F} \mathrm{NMR} \mathrm{(376.1} \mathrm{MHz,} \mathrm{CDCl}_{3}\right): \delta-138.8(\mathrm{q}$, ${ }^{1} J_{\mathrm{FB}}=31 \mathrm{~Hz}$ ). FT-IR (ATR): $3074(\mathrm{w}), 2955(\mathrm{w}), 1617(\mathrm{~m}), 1475(\mathrm{~s}), 760(\mathrm{~s}) \mathrm{cm}^{-1}$. UV-vis $\left(\mathrm{CH}_{2} \mathrm{Cl}_{2}\right): \lambda_{\max } 437 \mathrm{~nm}\left(\varepsilon=13200 \mathrm{M}^{-1} \mathrm{~cm}^{-1}\right), 345 \mathrm{~nm}\left(\varepsilon=3100 \mathrm{M}^{-1} \mathrm{~cm}^{-1}\right), 262 \mathrm{~nm}(\varepsilon=$ $4200 \mathrm{M}^{-1} \mathrm{~cm}^{-1}$ ). Mass Spec. (EI, +ve mode): exact mass calculated for $\left[\mathrm{C}_{18} \mathrm{H}_{14} \mathrm{BF}_{2} \mathrm{~N}_{3}\right]^{+},[\mathrm{M}]^{+}$: 321.1249; exact mass found: 321.1242; difference: $-2.2 \mathrm{ppm}$.

\section{BODIHY 10b}

From $8 \mathbf{b}(1.06 \mathrm{~g}, 3.70 \mathrm{mmol})$, dry $\mathrm{NEt}_{3}(1.12 \mathrm{~g}, 1.54 \mathrm{~mL}, 11.1 \mathrm{mmol})$, and $\mathrm{BF}_{3} \cdot \mathrm{OEt}_{2}(2.62 \mathrm{~g}, 2.28$ $\mathrm{mL} 18.5 \mathrm{mmol}$ ). The deep yellow/orange residue was washed with ice cold $\mathrm{MeOH}$ and the yellow precipitate was collected by vacuum filtration. Yield $=1.15 \mathrm{~g}, 93 \%$. M.p. $=179-180^{\circ} \mathrm{C} .{ }^{1} \mathrm{H}$ NMR $\left(399.8 \mathrm{MHz}, \mathrm{CDCl}_{3}\right): \delta 8.74\left(\mathrm{~d},{ }^{3} J_{\mathrm{HH}}=6 \mathrm{~Hz}, 1 \mathrm{H}, \operatorname{aryl~CH}\right), 7.99\left(\mathrm{ddd},{ }^{3} J_{\mathrm{HH}}=9 \mathrm{~Hz},{ }^{3} J_{\mathrm{HH}}=7 \mathrm{~Hz}\right.$, ${ }^{4} J_{\mathrm{HH}}=2 \mathrm{~Hz}, 1 \mathrm{H}$, aryl $\left.\mathrm{CH}\right), 7.68\left(\mathrm{~d},{ }^{3} J_{\mathrm{HH}}=9 \mathrm{~Hz}, 1 \mathrm{H}\right.$, aryl $\left.\mathrm{CH}\right), 7.64-7.60(\mathrm{~m}, 4 \mathrm{H}, \operatorname{aryl} \mathrm{CH}), 7.57-$ $7.52(\mathrm{~m}, 1 \mathrm{H}$, aryl $\mathrm{CH}), 7.51-7.47(\mathrm{~m}, 2 \mathrm{H}$, aryl $\mathrm{CH}), 7.44-7.41(\mathrm{~m}, 1 \mathrm{H}$, aryl $\mathrm{CH}), 7.16\left(\mathrm{~d},{ }^{3} J_{\mathrm{HH}}=\right.$ $9 \mathrm{~Hz}, 2 \mathrm{H}$, aryl $\mathrm{CH}), 2.34\left(\mathrm{~s}, 3 \mathrm{H}, \mathrm{CH}_{3}\right) .{ }^{11} \mathrm{~B}$ NMR $\left(128.3 \mathrm{MHz}, \mathrm{CDCl}_{3}\right): \delta 0.7\left(\mathrm{t},{ }^{1} J_{\mathrm{BF}}=33 \mathrm{~Hz}\right)$. ${ }^{13} \mathrm{C}\left\{{ }^{1} \mathrm{H}\right\}$ NMR (100.5 MHz, $\left.\mathrm{CDCl}_{3}\right): \delta 143.9,141.4,141.0,139.8\left(\mathrm{t}, J_{\mathrm{CF}}=2 \mathrm{~Hz}\right), 136.1,133.6$, $133.2,129.44,129.38,128.9,128.4,122.6,122.5,120.0\left(\mathrm{t}, J_{\mathrm{CF}}=2 \mathrm{~Hz}\right), 21.0 .{ }^{19} \mathrm{~F}$ NMR $(376.1 \mathrm{MHz}$, $\mathrm{CDCl}_{3}$ ): $\delta-138.7$ (q, ${ }^{1} J_{\mathrm{FB}}=33 \mathrm{~Hz}$ ). FT-IR (ATR): 3032 (w), 2957 (m), $2366(\mathrm{w}), 1736(\mathrm{w}), 1612$ (m), $1258(\mathrm{~m}), 817(\mathrm{~m}) \mathrm{cm}^{-1}$. UV-vis $\left(\mathrm{CH}_{2} \mathrm{Cl}_{2}\right): \lambda_{\max }=446 \mathrm{~nm}\left(\varepsilon=18400 \mathrm{M}^{-1} \mathrm{~cm}^{-1}\right), 347 \mathrm{~nm}(\varepsilon=$ $\left.4900 \mathrm{M}^{-1} \mathrm{~cm}^{-1}\right), 268 \mathrm{~nm}\left(\varepsilon=12000 \mathrm{M}^{-1} \mathrm{~cm}^{-1}\right), 251 \mathrm{~nm}\left(\varepsilon=11600 \mathrm{M}^{-1} \mathrm{~cm}^{-1}\right)$. Mass Spec. (EI, $+\mathrm{ve}$ mode): exact mass calculated for $\left[\mathrm{C}_{19} \mathrm{H}_{16} \mathrm{BF}_{2} \mathrm{~N}_{3}\right]^{+},[\mathrm{M}]^{+}$: 335.1405; exact mass found: 335.1399; difference: $-1.8 \mathrm{ppm}$.

\section{BODIHY 10c}

From $8 \mathrm{c}(1.12 \mathrm{~g}, 3.70 \mathrm{mmol})$, dry $\mathrm{NEt}_{3}(1.12 \mathrm{~g}, 1.54 \mathrm{~mL}, 11.1 \mathrm{mmol})$, and $\mathrm{BF}_{3} \cdot \mathrm{OEt}_{2}(2.62 \mathrm{~g}$, $2.28 \mathrm{~mL}, 18.5 \mathrm{mmol})$. The red solid was purified by column chromatography $\left(\mathrm{CH}_{2} \mathrm{Cl}_{2}\right.$, basic alumina) to afford $2 \mathbf{c}$ as a red semi-crystalline solid after solvent removal. Yield $=0.69 \mathrm{~g}, 53 \%$. M.p. 
$=163-165{ }^{\circ} \mathrm{C} .{ }^{1} \mathrm{H}$ NMR $\left(399.8 \mathrm{MHz}, \mathrm{CDCl}_{3}\right): \delta 8.67\left(\mathrm{~d},{ }^{3} J_{\mathrm{HH}}=6 \mathrm{~Hz}, 1 \mathrm{H}\right.$, aryl $\left.\mathrm{CH}\right), 7.91\left(\mathrm{t},{ }^{3} J_{\mathrm{HH}}=\right.$ $7 \mathrm{~Hz}, 1 \mathrm{H}$, aryl $\mathrm{CH}), 7.66-7.60(\mathrm{~m}, 5 \mathrm{H}$, aryl $\mathrm{CH}), 7.50-7.40(\mathrm{~m}, 4 \mathrm{H}$, aryl $\mathrm{CH}), 6.91\left(\mathrm{~d},{ }^{3} J_{\mathrm{HH}}=8 \mathrm{~Hz}\right.$, $2 \mathrm{H}$, aryl $\mathrm{CH}), 3.81\left(\mathrm{~s}, 3 \mathrm{H}, \mathrm{OCH}_{3}\right) .{ }^{11} \mathrm{~B} \mathrm{NMR}\left(128.3 \mathrm{MHz}, \mathrm{CDCl}_{3}\right): \delta 0.7\left(\mathrm{t},{ }^{1} J_{\mathrm{BF}}=32 \mathrm{~Hz}\right) .{ }^{13} \mathrm{C}\left\{{ }^{1} \mathrm{H}\right\}$ NMR (100.5 MHz, $\left.\mathrm{CDCl}_{3}\right): \delta$ 156.6, 141.3, 140.9, 139.6, 136.0, 129.7, 129.3, 128.9, 128.4, 122.5, 121.3, 116.7, 114.9, 114.1, 55.7. ${ }^{19} \mathrm{~F} \mathrm{NMR}\left(376.1 \mathrm{MHz}, \mathrm{CDCl}_{3}\right): \delta-138.9\left(\mathrm{q},{ }^{1} J_{\mathrm{FB}}=31 \mathrm{~Hz}\right)$. FT-IR (ATR): 3087 (w), 2938 (w), 1721 (m), 1615 (m), 1463 (s), 1276 (s), 1248 (s), 827 (s) cm $\mathrm{cm}^{-1}$. UV-vis $\left(\mathrm{CH}_{2} \mathrm{Cl}_{2}\right): \lambda_{\max }=453 \mathrm{~nm}\left(\varepsilon=22200 \mathrm{M}^{-1} \mathrm{~cm}^{-1}\right), 360 \mathrm{~nm}\left(\varepsilon=6000 \mathrm{M}^{-1} \mathrm{~cm}^{-1}\right), 275 \mathrm{~nm}(\varepsilon=$ $44900 \mathrm{M}^{-1} \mathrm{~cm}^{-1}$ ). Mass Spec. (EI, +ve mode): exact mass calculated for $\left[\mathrm{C}_{19} \mathrm{H}_{16} \mathrm{BF}_{2} \mathrm{~N}_{3} \mathrm{O}\right]^{+},[\mathrm{M}]^{+}$: 351.1354; exact mass found: 351.1362 ; difference: $+2.3 \mathrm{ppm}$.

\section{BODIHY 10d}

From $8 d(1.26 \mathrm{~g}, 3.70 \mathrm{mmol})$, dry $\mathrm{NEt}_{3}(1.12 \mathrm{~g}, 1.54 \mathrm{~mL}, 11.1 \mathrm{mmol})$, and $\mathrm{BF}_{3} \cdot \mathrm{OEt}_{2}(2.62 \mathrm{~g}$, $2.28 \mathrm{~mL}, 18.5 \mathrm{mmol})$. The dark orange solid was purified by column chromatography $\left(\mathrm{CH}_{2} \mathrm{Cl}_{2}\right.$, basic alumina) to afford $\mathbf{2 d}$ as an orange powder after solvent removal. Yield $=0.73 \mathrm{~g}, 51 \%$. M.p. $=$ $174-176{ }^{\circ} \mathrm{C} .{ }^{1} \mathrm{H} \mathrm{NMR}\left(399.8 \mathrm{MHz}, \mathrm{CDCl}_{3}\right): \delta 8.77\left(\mathrm{~d},{ }^{3} J_{\mathrm{HH}}=6 \mathrm{~Hz}, 1 \mathrm{H}\right.$, aryl $\left.\mathrm{CH}\right), 8.02\left(\mathrm{ddd},{ }^{3} J_{\mathrm{HH}}=\right.$ $\left.9 \mathrm{~Hz},{ }^{3} J_{\mathrm{HH}}=7 \mathrm{~Hz},{ }^{4} J_{\mathrm{HH}}=2 \mathrm{~Hz}, 1 \mathrm{H}, \operatorname{aryl} \mathrm{CH}\right), 7.72\left(\mathrm{t},{ }^{3} J_{\mathrm{HH}}=8 \mathrm{~Hz}, 3 \mathrm{H}\right.$, aryl $\left.\mathrm{CH}\right), 7.66-7.62(\mathrm{~m}, 2 \mathrm{H}$, aryl $\mathrm{CH}), 7.59-7.55(\mathrm{~m}, 1 \mathrm{H}$, aryl $\mathrm{CH}), 7.51-7.47(\mathrm{~m}, 2 \mathrm{H}$, aryl $\mathrm{CH}), 7.45-7.41(\mathrm{~m}, 1 \mathrm{H}$, aryl $\mathrm{CH})$, $7.37\left(\mathrm{ddt},{ }^{3} J_{\mathrm{HH}}=9 \mathrm{~Hz},{ }^{3} J_{\mathrm{HH}}=8 \mathrm{~Hz},{ }^{4} J_{\mathrm{HH}}=2 \mathrm{~Hz}, 2 \mathrm{H}\right.$, aryl $\left.\mathrm{CH}\right), 7.13-7.09(\mathrm{~m}, 1 \mathrm{H}, \operatorname{aryl} \mathrm{CH}) .{ }^{11} \mathrm{~B}$ $\operatorname{NMR}\left(128.3 \mathrm{MHz}, \mathrm{CDCl}_{3}\right): \delta 0.7\left(\mathrm{t},{ }^{1} J_{\mathrm{BF}}=33 \mathrm{~Hz}\right) \cdot{ }^{13} \mathrm{C}\left\{{ }^{1} \mathrm{H}\right\}\left(100.5 \mathrm{MHz}, \mathrm{CDCl}_{3}\right): \delta 167.3,141.9$, $141.5,140.5,135.6,130.7,129.4,129.0,128.9,126.0\left(\mathrm{q},{ }^{1} J_{\mathrm{CF}}=4 \mathrm{~Hz}, \mathrm{C} F_{3}\right) 124.7,123.6,123.2$, 119.0, 118.6. ${ }^{19} \mathrm{~F}$ NMR $\left(376.1 \mathrm{MHz}, \mathrm{CDCl}_{3}\right): \delta-138.6\left(\mathrm{q},{ }^{1} J_{\mathrm{FB}}=33 \mathrm{~Hz}, \mathrm{~B} F_{2}\right),-61.8\left(\mathrm{~s}, \mathrm{C} F_{3}\right)$. FTIR (ATR): 3051 (w), 2965 (w), 2862 (w), 1707 (s), 1604 (s), 1155 (s) cm ${ }^{-1}$. UV-vis $\left(\mathrm{CH}_{2} \mathrm{Cl}_{2}\right)$ : $\lambda_{\max }$ $=432 \mathrm{~nm}\left(\varepsilon=25700 \mathrm{M}^{-1} \mathrm{~cm}^{-1}\right), 329 \mathrm{~nm}\left(\varepsilon=6100 \mathrm{M}^{-1} \mathrm{~cm}^{-1}\right), 268 \mathrm{~nm}\left(\varepsilon=16500 \mathrm{M}^{-1} \mathrm{~cm}^{-1}\right)$. Mass Spec. (EI, +ve mode): exact mass calculated for $\left[\mathrm{C}_{19} \mathrm{H}_{12} \mathrm{BF}_{5} \mathrm{~N}_{3}\right]^{+}$, $[\mathrm{M}-\mathrm{H}]^{+}:$388.1044; exact mass found: 388.1040; difference: $-1.0 \mathrm{ppm}$.

\section{BODIHY 10e}

From $8 \mathrm{e}(1.20 \mathrm{~g}, 3.70 \mathrm{mmol})$, dry $\mathrm{NEt}_{3}(1.12 \mathrm{~g}, 1.54 \mathrm{~mL}, 11.1 \mathrm{mmol})$, and $\mathrm{BF}_{3} \cdot \mathrm{OEt}_{2}(2.62 \mathrm{~g}$, $2.28 \mathrm{~mL}, 18.5 \mathrm{mmol})$. The red solid was purified by column chromatography $\left(\mathrm{CH}_{2} \mathrm{Cl}_{2}\right.$, basic alumina) to afford $2 \mathbf{e}$ as an orange/red powder after solvent removal. Yield $=0.84 \mathrm{~g}, 61 \%$. M.p. $=$ 187-189 ${ }^{\circ} \mathrm{C} .{ }^{1} \mathrm{H}$ NMR $\left(399.8 \mathrm{MHz}, \mathrm{CDCl}_{3}\right): \delta 8.79\left(\mathrm{~d},{ }^{3} J_{\mathrm{HH}}=6 \mathrm{~Hz}, 1 \mathrm{H}\right.$, aryl $\left.\mathrm{CH}\right), 8.11(\mathrm{br} \mathrm{s}, 1 \mathrm{H}$, 
aryl $\mathrm{CH}), 8.01-7.97(\mathrm{~m}, 2 \mathrm{H}$, aryl $\mathrm{CH}), 7.85\left(\mathrm{t},{ }^{3} J_{\mathrm{HH}}=8 \mathrm{~Hz}, 2 \mathrm{H}\right.$, aryl $\left.\mathrm{CH}\right), 7.78\left(\mathrm{~d},{ }^{3} J_{\mathrm{HH}}=8 \mathrm{~Hz}, 1 \mathrm{H}\right.$, aryl $\mathrm{CH}), 7.71-7.66(\mathrm{~m}, 3 \mathrm{H}$, aryl $\mathrm{CH}), 7.57-7.51(\mathrm{~m}, 3 \mathrm{H}$, aryl $\mathrm{CH}), 7.48-7.42(\mathrm{~m}, 2 \mathrm{H}$, aryl $\mathrm{CH})$, $7.37\left(\mathrm{ddd},{ }^{3} J_{\mathrm{HH}}=8 \mathrm{~Hz},{ }^{3} J_{\mathrm{HH}}=7 \mathrm{~Hz},{ }^{4} J_{\mathrm{HH}}=1 \mathrm{~Hz}, 1 \mathrm{H}\right.$, aryl CH). ${ }^{11} \mathrm{~B} \mathrm{NMR}\left(128.3 \mathrm{MHz}, \mathrm{CDCl}_{3}\right): \delta$ $0.9\left(\mathrm{t},{ }^{1} J_{\mathrm{BF}}=33 \mathrm{~Hz}\right) .{ }^{13} \mathrm{C}\left\{{ }^{1} \mathrm{H}\right\} \mathrm{NMR}\left(100.5 \mathrm{MHz}, \mathrm{CDCl}_{3}\right): \delta 143.9,141.4,141.3,140.0\left(\mathrm{t}, J_{\mathrm{CF}}=\right.$ $2 \mathrm{~Hz}), 136.0,134.1,133.9,130.9,129.4,129.0,128.6,128.5,128.1,127.6,126.2,124.7,122.9$, 122.7, 120.1, $116.4\left(\mathrm{t}, J_{\mathrm{CF}}=3 \mathrm{~Hz}\right) .{ }^{19} \mathrm{~F}$ NMR $\left(376.1 \mathrm{MHz}, \mathrm{CDCl}_{3}\right): \delta-138.5\left(\mathrm{q},{ }^{1} J_{\mathrm{FB}}=32 \mathrm{~Hz}\right)$. FTIR (ATR): 3055 (m), 1618 (s), 1597 (m), 1479 (s), 1462 (s), 1434 (s), cm ${ }^{-1}$. UV-vis $\left(\mathrm{CH}_{2} \mathrm{Cl}_{2}\right): \lambda_{\max }$ $=451 \mathrm{~nm}\left(\varepsilon=13600 \mathrm{M}^{-1} \mathrm{~cm}^{-1}\right), 343 \mathrm{~nm}\left(\varepsilon=3900 \mathrm{M}^{-1} \mathrm{~cm}^{-1}\right), 269 \mathrm{~nm}\left(\varepsilon=30200 \mathrm{M}^{-1} \mathrm{~cm}^{-1}\right)$. Mass Spec. (EI, +ve mode): exact mass calculated for $\left[\mathrm{C}_{22} \mathrm{H}_{16} \mathrm{BF}_{2} \mathrm{~N}_{3}\right]^{+},[\mathrm{M}]^{+}$: 371.1405; exact mass found: 371.1411; difference: $+1.6 \mathrm{ppm}$.

\section{BODIHY 11b}

From 9b, $(0.874 \mathrm{~g}, 3.70 \mathrm{mmol})$, dry $\mathrm{NEt}_{3}(1.12 \mathrm{~g}, 1.54 \mathrm{~mL}, 11.1 \mathrm{mmol})$, and $\mathrm{BF}_{3} \cdot \mathrm{OEt}_{2}(2.62 \mathrm{~g}$, $2.28 \mathrm{~mL} 18.5 \mathrm{mmol})$. The yellow solid was purified by column chromatography (4:1 hexane/ethyl acetate, silica gel) to afford $\mathbf{1 1 b}$ as a yellow semicrystalline solid after solvent removal. Yield = 0.57 g, 55\%. M.p. $=182-184{ }^{\circ} \mathrm{C} .{ }^{1} \mathrm{H}$ NMR $\left(399.8 \mathrm{MHz}, \mathrm{CDCl}_{3}\right): \delta 8.67\left(\mathrm{~d},{ }^{3} J_{\mathrm{HH}}=6 \mathrm{~Hz}, 1 \mathrm{H}\right.$, aryl $\mathrm{CH}), 8.25\left(\mathrm{ddd},{ }^{3} J_{\mathrm{HH}}=9 \mathrm{~Hz},{ }^{3} J_{\mathrm{HH}}=8 \mathrm{~Hz},{ }^{4} J_{\mathrm{HH}}=2 \mathrm{~Hz}, 1 \mathrm{H}\right.$, aryl $\left.\mathrm{CH}\right), 7.93\left(\mathrm{~d},{ }^{3} J_{\mathrm{HH}}=8 \mathrm{~Hz}, 1 \mathrm{H}\right.$, aryl $\mathrm{CH}), 7.67-7.59(\mathrm{~m}, 3 \mathrm{H}), 7.23\left(\mathrm{~d},{ }^{3} J_{\mathrm{HH}}=8 \mathrm{~Hz}, 2 \mathrm{H}\right.$, aryl $\left.\mathrm{CH}\right), 2.38\left(\mathrm{~s}, 3 \mathrm{H}, \mathrm{CH}_{3}\right) .{ }^{11} \mathrm{~B} \mathrm{NMR}(128.3$ $\left.\mathrm{MHz}, \mathrm{CDCl}_{3}\right): \delta 0.2\left(\mathrm{t},{ }^{1} J_{\mathrm{BF}}=32 \mathrm{~Hz}\right) .{ }^{13} \mathrm{C}\left\{{ }^{1} \mathrm{H}\right\} \mathrm{NMR}\left(100.5 \mathrm{MHz}, \mathrm{CDCl}_{3}\right): \delta 142.9,142.5,141.5$, 140.2 , 136.8, 129.7, 123.5, 120.63, 120.60, 120.58, 115.6, 21.1. ${ }^{19} \mathrm{~F} \mathrm{NMR}\left(376.1 \mathrm{MHz}, \mathrm{CDCl}_{3}\right): \delta$ $-133.8\left(\mathrm{q},{ }^{1} J_{\mathrm{FB}}=31 \mathrm{~Hz}\right)$. FT-IR (ATR): $3096(\mathrm{w}), 2952(\mathrm{w}), 2223(\mathrm{~s}), 1725(\mathrm{w}), 1624(\mathrm{~s}), 1281(\mathrm{~m})$, $810(\mathrm{~m}) \mathrm{cm}^{-1}$. UV-vis $\left(\mathrm{CH}_{2} \mathrm{Cl}_{2}\right): \lambda_{\max }=420 \mathrm{~nm}\left(\varepsilon=9400 \mathrm{M}^{-1} \mathrm{~cm}^{-1}\right), 325 \mathrm{~nm}\left(\varepsilon=2200 \mathrm{M}^{-1} \mathrm{~cm}^{-1}\right)$, $255 \mathrm{~nm}\left(\varepsilon=4800 \mathrm{M}^{-1} \mathrm{~cm}^{-1}\right)$. Mass Spec. (EI, +ve mode): exact mass calculated for $\left[\mathrm{C}_{19} \mathrm{H}_{16} \mathrm{BF}_{2} \mathrm{~N}_{3}\right]^{+}$, $[\mathrm{M}]^{+}:$284.1045; exact mass found: 284.1052; difference: $+2.5 \mathrm{ppm}$.

\section{Radical cation $10 c^{\bullet+}$}

In an $\mathrm{N}_{2}$ filled glovebox, a solution of $\mathrm{NOBF}_{4}(0.050 \mathrm{~g}, 0.43 \mathrm{mmol})$ in $\mathrm{CH}_{3} \mathrm{CN}(1 \mathrm{~mL})$ was added dropwise to a stirring solution of BODIHY $2 \mathrm{c}(0.050 \mathrm{~g}, 0.14 \mathrm{mmol})$ in $\mathrm{CH}_{2} \mathrm{Cl}_{2}(9 \mathrm{~mL})$. Upon addition, the solution changed from red to a deep maroon/purple colour and was stirred for $30 \mathrm{~min}$ before it was taken to dryness in vacuo to afford a maroon/purple solid. The solid was dissolved in $\mathrm{CH}_{2} \mathrm{Cl}_{2}(20 \mathrm{~mL})$ and the solution was passed through a pad of celite to remove excess $\mathrm{NOBF}_{4}$ 
before the solvent was once again removed in vacuo to afford $\mathbf{1 0}^{\mathbf{*}}$ as a maroon/purple solid. Yield $=0.052$ g, 84\%. M.p. $=208-210{ }^{\circ} \mathrm{C}$. FT-IR (ATR): $3261(\mathrm{w}), 3118(\mathrm{~m}), 1685(\mathrm{~m}), 1627(\mathrm{~m}), 1603$ (m), $1543(\mathrm{~s}), 1515(\mathrm{~s}), 1488(\mathrm{~s}), 1449(\mathrm{~m}), 1118(\mathrm{~s}) \mathrm{cm}^{-1}$. UV-vis $\left(\mathrm{CH}_{2} \mathrm{Cl}_{2}\right): \lambda_{\max }=777 \mathrm{~nm}(\varepsilon=$ $\left.300 \mathrm{M}^{-1} \mathrm{~cm}^{-1}\right), 703 \mathrm{~nm}\left(\varepsilon=200 \mathrm{M}^{-1} \mathrm{~cm}^{-1}\right), 482 \mathrm{~nm}\left(\varepsilon=2500 \mathrm{M}^{-1} \mathrm{~cm}^{-1}\right), 385 \mathrm{~nm}\left(\varepsilon=9400 \mathrm{M}^{-1}\right.$

$\left.\mathrm{cm}^{-1}\right), 319 \mathrm{~nm}\left(\varepsilon=19200 \mathrm{M}^{-1} \mathrm{~cm}^{-1}\right)$. Mass Spec. (EI, +ve mode): exact mass calculated for $\left[\mathrm{C}_{19} \mathrm{H}_{16} \mathrm{BF}_{2} \mathrm{~N}_{3} \mathrm{O}\right]^{+}:$351.1354; exact mass found: 351.1352; difference: $-0.6 \mathrm{ppm}$.

\section{Attempted oxidation of BODIHY 10a}

In an $\mathrm{N}_{2}$ filled glovebox, a solution of $\mathrm{NOBF}_{4}(0.055 \mathrm{~g}, 0.47 \mathrm{mmol})$ in $\mathrm{CH}_{3} \mathrm{CN}(1 \mathrm{~mL})$ was added dropwise to a stirred solution of BODIHY 10a $(0.050 \mathrm{~g}, 0.16 \mathrm{mmol})$ in $\mathrm{CH}_{3} \mathrm{CN}(9 \mathrm{~mL})$. Upon addition, the colour of the solution changed from yellow to turquoise and it was stirred for $30 \mathrm{~min}$ before it was concentrated in vacuo to afford a turquoise film that rapidly decomposed to an insoluble brown/red solid. Yield $=0.093$ g, 93\%. M.p. $=239-241^{\circ} \mathrm{C}$. FT-IR (ATR): $3087(\mathrm{w})$, 2974 (w), 1616 (m), 1477 (s), 761 (m) cm ${ }^{-1}$. Mass Spec. (EI, +ve mode): exact mass calculated for $\left[\mathrm{C}_{36} \mathrm{H}_{26} \mathrm{~B}_{2} \mathrm{~F}_{4} \mathrm{~N}_{6}\right]^{+},[2 \mathrm{M}-2 \mathrm{H}]^{+}: 640.2341$; exact mass found: 640.2341; difference: $0.0 \mathrm{ppm}$.

\section{Attempted oxidation of BODIHY 10e}

In an $\mathrm{N}_{2}$ filled glovebox, a solution of $\mathrm{NOBF}_{4}(0.055 \mathrm{~g}, 0.47 \mathrm{mmol})$ in $\mathrm{CH}_{3} \mathrm{CN}(1 \mathrm{~mL})$ was added dropwise to a stirred solution of complex $10 \mathrm{e}(0.058 \mathrm{~g}, 0.16 \mathrm{mmol})$ in $\mathrm{CH}_{3} \mathrm{CN}(9 \mathrm{~mL})$. Upon addition, the colour of the solution changed from orange to deep red and it was stirred for $60 \mathrm{~min}$ above before being concentrated in vacuo to afford a deep red film that rapidly decomposed to an insoluble brown solid. Yield $=0.097$ g, 84\%. M.p. >250 ${ }^{\circ}$ C. FT-IR (ATR): 3292 (w), 3110 (m), 1684 (m), 1620 (s), 1593 (m), 1488 (s), 1453 (s), 1441 (s), 1617 (m), 1053 (m) cm ${ }^{-1}$. Mass Spec. (EI, +ve mode): exact mass calculated for $\left[\mathrm{C}_{44} \mathrm{H}_{30} \mathrm{~B}_{2} \mathrm{~F}_{4} \mathrm{~N}_{6}\right]^{+}$, [2M-2H $]^{+}: 740.2654$; exact mass found: 740.2651 ; difference: $-0.4 \mathrm{ppm}$.

\section{REFERENCES}

[1] D. Frath, J. Massue, G. Ulrich, R. Ziessel, Angew. Chem. Int. Ed. 2014, 53, 2290-2310.

[2] A. Loudet, K. Burgess, Chem. Rev. 2007, 107, 4891-4932.

[3] a) A. C. Sedgwick, R. S. L. Chapman, J. E. Gardiner, L. R. Peacock, G. Kim, J. Yoon, S. D. Bull, T. D. James, Chem. Commun. 2017, 53, 10441-10443; b) Y. Kage, S. Mori, M. Ide, A. 
Saeki, H. Furuta, S. Shimizu, Mater. Chem. Front. 2018, 2, 112-120; c) W. Sheng, Y. Wu, C. Yu, P. Bobadova-Parvanova, E. Hao, L. Jiao, Org. Lett. 2018, 20, 2620-2623; d) Y. Xu, T. Feng, T. Yang, H. Wei, H. Yang, G. Li, M. Zhao, S. Liu, W. Huang, Q. Zhao, ACS Appl. Mater. Interfaces 2018, 10, 16299-16307.

[4] G. Nawn, S. R. Oakley, M. B. Majewski, R. McDonald, B. O. Patrick, R. G. Hicks, Chem. Sci. 2013, 4, 612-621.

[5] a) J. F. Araneda, W. E. Piers, B. Heyne, M. Parvez, R. McDonald, Angew. Chem. Int. Ed. 2011, 50, 12214-12217; b) S. Mula, N. Leclerc, P. Lévêque, P. Retailleau, G. Ulrich, J. Org. Chem. 2018, 83, 14406-14418.

[6] a) I.-S. Tamgho, A. Hasheminasab, J. T. Engle, V. N. Nemykin, C. J. Ziegler, J. Am. Chem. Soc. 2014, 136, 5623-5626; b) Q. Huaulmé, A. Mirloup, P. Retailleau, R. Ziessel, Org. Lett. 2015, 17, 2246-2249; c) A. Mirloup, Q. Huaulmé, N. Leclerc, P. Lévêque, T. Heiser, P. Retailleau, R. Ziessel, Chem. Commun. 2015, 51, 14742-14745; d) Y. V. Zatsikha, D. B. Nemez, R. L. Davis, S. Singh, D. E. Herbert, A. J. King, C. J. Ziegler, V. N. Nemykin, Chem. Eur. J. 2017, 23, 14786-14796.

[7] a) M.-C. Chang, E. Otten, Chem. Commun. 2014, 50, 7431-7433; b) S. M. Barbon, P. A. Reinkeluers, J. T. Price, V. N. Staroverov, J. B. Gilroy, Chem. Eur. J. 2014, 20, 1134011344; c) M. Hesari, S. M. Barbon, V. N. Staroverov, Z. Ding, J. B. Gilroy, Chem. Commun. 2015, 51, 3766-3769; d) R. R. Maar, R. Zhang, D. G. Stephens, Z. Ding, J. B. Gilroy, Angew. Chem. Int. Ed. 2019, 58, 1052-1056.

[8] T. Kowada, H. Maeda, K. Kikuchi, Chem. Soc. Rev. 2015, 44, 4953-4972.

[9] a) Q. Lin, D. Buccella, J. Mater. Chem. B 2018, 6, 7247-7256; b) M. K. Raza, S. Gautam, P. Howlader, A. Bhattacharyya, P. Kondaiah, A. R. Chakravarty, Inorg. Chem. 2018, 57, 1437414385; c) Q. Wang, D. K. P. Ng, P.-C. Lo, J. Mater. Chem. B 2018, 6, 3285-3296; d) C. S. Wijesooriya, J. A. Peterson, P. Shrestha, E. J. Gehrmann, A. H. Winter, E. A. Smith, Angew. Chem. Int. Ed. 2018, 57, 12685-12689; e) Y. Zhang, K.-H. Song, S. Tang, L. Ravelo, J. Cusido, C. Sun, H. F. Zhang, F. M. Raymo, J. Am. Chem. Soc. 2018, 140, 12741-12745; f) H. Zhu, Z. Zhang, S. Long, J. Du, J. Fan, X. Peng, Nat. Protoc. 2018, 13, 2348-2361.

[10] a) Z. Zhang, B. Xu, J. Su, L. Shen, Y. Xie, H. Tian, Angew. Chem. Int. Ed. 2011, 50, 1165411657; b) K. Perumal, J. A. Garg, O. Blacque, R. Saiganesh, S. Kabilan, K. K. Balasubramanian, K. Venkatesan, Chem. Asian J. 2012, 7, 2670-2677; c) T. T. Vu, M. Dvorko, E. Y. Schmidt, J.-F. Audibert, P. Retailleau, B. A. Trofimov, R. B. Pansu, G. Clavier, 
R. Méallet-Renault, J. Phys. Chem. C 2013, 117, 5373-5385; d) R. Yoshii, A. Hirose, K. Tanaka, Y. Chujo, Chem. Eur. J. 2014, 20, 8320-8324; e) S. Mukherjee, P. Thilagar, Chem. Eur. J. 2014, 20, 9052-9062; f) C. F. A. Gomez-Duran, R. Hu, G. Feng, T. Li, F. Bu, M. Arseneault, B. Liu, E. Peña-Cabrera, B. Z. Tang, ACS Appl. Mater. Interfaces 2015, 7, 15168-15176; g) R. R. Maar, J. B. Gilroy, J. Mater. Chem. C 2016, 4, 6478-6482; h) Z. Chen, Y. Liu, W. Wagner, V. Stepanenko, X. Ren, S. Ogi, F. Würthner, Angew. Chem. Int. Ed. 2017, 56, 5729-5733; i) K. I. Lugovik, A. K. Eltyshev, P. O. Suntsova, P. A. Slepukhin, E. Benassi, N. P. Belskaya, Chem. Asian J. 2018, 13, 311-324.

[11] a) J. Mei, Y. Hong, J. W. Y. Lam, A. Qin, Y. Tang, B. Z. Tang, Adv. Mater. 2014, 26, 54295479; b) J. Mei, N. L. C. Leung, R. T. K. Kwok, J. W. Y. Lam, B. Z. Tang, Chem. Rev. 2015, $115,11718-11940$.

[12] a) L. A. Tatum, X. Su, I. Aprahamian, Acc. Chem. Res. 2014, 47, 2141-2149; b) I. Aprahamian, Chem. Commun. 2017, 53, 6674-6684; c) J. D. Harris, M. J. Moran, I. Aprahamian, Proc. Nat. Acad. Sci. U.S.A. 2018, 115, 9414-9422.

[13] a) Y. Yang, R. P. Hughes, I. Aprahamian, J. Am. Chem. Soc. 2012, 134, 15221-15224; b) Y. Yang, X. Su, C. N. Carroll, I. Aprahamian, Chem. Sci. 2012, 3, 610-613; c) Y. Yang, R. P. Hughes, I. Aprahamian, J. Am. Chem. Soc. 2014, 136, 13190-13193; d) H. Qian, M. E. Cousins, E. H. Horak, A. Wakefield, M. D. Liptak, I. Aprahamian, Nat. Chem. 2017, 9, 83-87; e) H. Qian, Y.-Y. Wang, D.-S. Guo, I. Aprahamian, J. Am. Chem. Soc. 2017, 139, 1037-1040.

[14] CRC Handbook of Chemistry and Physics, $96^{\text {th }}$ ed.; Haynes, W. M., Ed.; CRC Press: Boca Raton, FL, 2015.

[15] a) S. M. Barbon, J. T. Price, P. A. Reinkeluers, J. B. Gilroy, Inorg. Chem. 2014, 53, 1058510593; b) M.-C. Chang, A. Chantzis, D. Jacquemin, E. Otten, Dalton Trans. 2016, 45, 94779484.

[16] S. Sasaki, G. P. C. Drummen, G.-i. Konishi, J. Mater. Chem. C 2016, 4, 2731-2743.

[17] F. Würthner, T. E. Kaiser, C. R. Saha-Möller, Angew. Chem. Int. Ed. 2011, 50, 3376-3410.

[18] R. G. Hicks, Org. Biomol. Chem. 2007, 5, 1321-1338.

[19] a) M. Gomberg, J. Am. Chem. Soc. 1900, 22, 757-771; b) M. Ballester, J. Riera-Figueras, J. Castaner, C. Badfa, J. M. Monso, J. Am. Chem. Soc. 1971, 93, 2215-2225; c) B. Kahr, D. Van Engen, P. Gopalan, Chem. Mater. 1993, 5, 729-732. 
[20] a) P. B. Sogo, M. Nakazaki, M. Calvin, J. Chem. Phys. 1957, 26, 1343-1345; b) D. H. Reid, Tetrahedron 1958, 3, 339-352; c) P. A. Koutentis, Y. Chen, Y. Cao, T. P. Best, M. E. Itkis, L. Beer, R. T. Oakley, A. W. Cordes, C. P. Brock, R. C. Haddon, J. Am. Chem. Soc. 2001, 123, 3864-3871.

[21] a) J. B. Gilroy, M. J. Ferguson, R. McDonald, B. O. Patrick, R. G. Hicks, Chem. Commun. 2007, 126-128; b) A. Van Belois, R. R. Maar, M. S. Workentin, J. B. Gilroy, Inorg. Chem. 2019, 58, 834-843.

[22] R. N. Butler, S. M. Johnston, J. Chem. Soc., Perkin Trans. 1 1984, 2109-2116.

[23] H. Abuo-Melha, A. A. Fadda, Spectrochim. Acta, Part A 2012, 89, 123-128.

[24] S. Fery-Forgues, D. Lavabre, J. Chem. Educ. 1999, 76, 1260-1264.

[25] Bruker-AXS, SAINT version 2013.8, 2013, Bruker-AXS Madison, WI 53711, USA.

[26] Bruker-AXS, SADABS version 2012.1, 2012, Bruker-AXS, Madison, WI 53711, USA.

[27] G. M. Sheldrick, Acta Cryst. 2015, A71, 3-8.

[28] G. M. Sheldrick, Acta Cryst. 2015, C71, 3-8.

[29] M. J. Frisch, G. W. Trucks, H. B. Schlegel, G. E. Scuseria, M. A. Robb, J. R. Cheeseman, G. Scalmani, V. Barone, B. Mennucci, G. A. Petersson, H. Nakatsuji, M. Caricato, X. Li, H. P. Hratchian, A. F. Izmaylov, J. Bloino, G. Zheng, J. L. Sonnenberg, M. Hada, M. Ehara, K. Toyota, R. Fukuda, J. Hasegawa, M. Ishida, T. Nakajima, Y. Honda, O. Kitao, H. Nakai, T. Vreven, J. A. Montgomery Jr., J. E. Peralta, F. Ogliaro, M. Bearpark, J. J. Heyd, E. Brothers, K. N. Kudin, V. N. Staroverov, R. Kobayashi, J. Normand, K. Raghavachari, A. Rendell, J. C. Burant, S. S. Iyengar, J. Tomasi, M. Cossi, N. Rega, J. M. Millam, M. Klene, J. E. Knox, J. B. Cross, V. Bakken, C. Adamo, J. Jaramillo, R. Gomperts, R. E. Stratmann, O. Yazyev, A. J. Austin, R. Cammi, C. Pomelli, J. W. Ochterski, R. L. Martin, K. Morokuma, V. G. Zakrzewski, G. A. Voth, P. Salvador, J. J. Dannenberg, S. Dapprich, A. D. Daniels, Ö. Farkas, J. B. Foresman, J. V. Ortiz, J. Cioslowski, D. J. Fox, Gaussian Development Version, Revision I.13, Gaussian Inc., Wallingford, CT, 2016. 